\title{
Evaluation of hydrochars from lignin hydrous pyrolysis to produce biocokes after carbonization
}

\author{
M. Castro-Díaz ${ }^{\mathrm{a}, *}$, C.N. Uguna ${ }^{\mathrm{a}, \mathrm{b}}$, L. Florentino ${ }^{\mathrm{c}}$, E. Díaz-Faes ${ }^{\mathrm{c}}$, L.A. Stevens ${ }^{\mathrm{a}}$, C. \\ Barriocanal $^{c}$, C.E. Snape ${ }^{\mathrm{a}}$ \\ ${ }^{a}$ University of Nottingham, Faculty of Engineering, Energy Technologies Building, Triumph \\ Road, Nottingham, NG7 2TU, UK \\ ${ }^{\mathrm{b}}$ Centre for Environmental Geochemistry, British Geological Survey, Keyworth, Nottingham, \\ $N G 125 G G, U K$ \\ ${ }^{\mathrm{c}}$ Instituto Nacional del Carbón (INCAR), CSIC, Apartado 73, 33011 Oviedo, Spain
}

\begin{abstract}
Hydrochars were obtained after hydrous pyrolysis of a pine Kraft lignin using different reaction conditions (temperature, water content and residence time) and the residues were characterized through a wide range of analytical techniques including high-temperature rheometry, solid-state ${ }^{13} \mathrm{C}$ nuclear magnetic resonance (NMR), thermal gravimetric analysis (TGA), diffuse reflectance infrared Fourier transform spectroscopy (DRIFTS) and field emission scanning electron microscopy (FE-SEM). The results indicated that an increase in reaction temperature, an increase in residence time or a decrease in water content reduces the amount of fluid material in the residue. The hydrous pyrolysis conditions studied were not able to increase the maturation of lignin, which would result in an increase in the resolidification temperature, but reduced the amount of mineral matter in the hydrochar produced. On the other hand, the hydrochars obtained from pristine lignin, torrefied lignin $\left(300{ }^{\circ} \mathrm{C}, 1\right.$ hour) and their 50:50 wt.\%/wt.\% blend at temperatures of $350{ }^{\circ} \mathrm{C}$ after 6 hours using $30 \mathrm{ml}$ of water had lower ash contents $(<2 \mathrm{wt} . \%)$ than the parent lignin $(2.5 \mathrm{wt} . \%)$ and a high rank good coking coal $(10 \mathrm{wt} . \%)$. However, the reactivity of the resulting biocokes $(>45 \%)$ is excessively high compared to that of the good coking coal $(10 \%)$ and the microstrength of the biocokes $\left(\mathrm{R}_{1}<1 \%\right)$ is much lower than that of the coal $\left(\mathrm{R}_{1}=17 \%\right)$. These findings could be rationalized by the high total porosity $(>39 \%)$ and high microporous surface areas $\left(>400 \mathrm{~m}^{2} / \mathrm{g}\right)$ of the biocokes and high alkalinity index of the lignins $(>27 \%)$ compared to those of the coke $\left(27 \%\right.$ and $\left.145 \mathrm{~m}^{2} / \mathrm{g}\right)$ and coal $(0.6 \%)$, respectively. Furthermore, the biocoke derived from the hydrous pyrolysed torrefied lignin did not agglomerate, which could not be explained by changes in the chemical properties of the material and requires further investigation.
\end{abstract}

\footnotetext{
* Corresponding author.

E-mail address: miguel.castro@nottingham.ac.uk (M. Castro Díaz)
} 


\section{Introduction}

The substitution of coking coals with biomass materials is receiving a lot of attention in recent times due to the simultaneous reduction in material costs and non-renewable carbon emissions in the carbonization process [1-11]. The resultant coke obtained by the partial substitution of coal by biomass during coke making has been termed biocoke. It has been suggested that biomass addition can be increased without impairing biocoke strength and yield by increasing the biomass particle size and its density through compressive forming [12]. Charcoal has also been studied to reduce non-renewable carbon emissions $[4,13,14]$. The substitution of coal with 2-3 wt.\% charcoal has been proven to produce biocoke with similar reactivity behavior to $\mathrm{CO}_{2}$ to that of coke from coal [13]. Even an increase to $5 \mathrm{wt} . \%$ charcoal addition in the biocoke could have a beneficial impact in $\mathrm{CO}_{2}$ emissions by reducing the thermal reserve zone temperature of the blast furnace that leads to a reduction in coke rate. Other researchers [15] have also suggested that hydrothermal carbonization (also termed as hydrous pyrolysis) of biomass can produce residues with properties similar to those of cokes obtained from coal, basing this assumption on the tensile strength of the residues at ambient temperature. However, none of these studies take into consideration the hot mechanical strength of the biocoke, which is one of the main criteria in order to establish the suitability of the biocoke for industrial application.

It is also well known that the char yield obtained from biomass is limited by the different extents of thermal degradation and concentrations of its main constituents hemicellulose, cellulose and lignin. Indeed, the biomass constituent lignin produces higher char yields than cellulose and hemicellulose since it is the only one with aromatic structures. Lignin is an interesting feedstock for biocoke production because it has $\mathrm{H} / \mathrm{C}$ and $\mathrm{O} / \mathrm{C}$ ratios closer to those from coal than the parent biomass, it is produced in vast quantities as a by-product in the pulp and paper industry (mainly as Kraft lignin) and will be obtained as a waste product in future bio-refineries [16]. For instance, lignin has been used as a binder of anthracite fines to produce foundry coke briquettes and the strength of the briquettes increased with an increase in hardwood lignin concentration up to around $6 \mathrm{wt. \%}$ [17]. However, lignin is also characterized by a high degree of swelling upon heating that can cause operational problems in the coke oven (e.g. high wall pressures, hard pushes during oven discharge) and diminish the biocoke strength. Torrefaction, which consists on a pyrolysis treatment at temperatures between $200-300{ }^{\circ} \mathrm{C}$ and has been used to increase the energy density of lignin [18], can reduce the level of swelling and increase its bulk density.

Therefore, the aims of this work are to elucidate whether torrefaction can improve the coking properties of a pine Kraft lignin and whether the residues obtained after hydrous pyrolysis of lignin in pristine and torrefied forms can be used to produce a fully renewable biocoke with good hot mechanical strength and reactivity. In this work, biocoke will be referred to as the coke obtained from hydrochars derived from pristine lignin, torrefied lignin and their 50:50 wt.\%/wt.\% blend without the presence of coal.

\section{Materials and methods}

\subsection{Materials}

The pine Kraft lignin used in this study was obtained from MeadWestvaco (USA) and supplied as a dark brown powder ( $>99.5 \mathrm{wt} . \%$ lignin). The pine Kraft lignin was torrefied at $250{ }^{\circ} \mathrm{C}$ and $300{ }^{\circ} \mathrm{C}$ for 1 hour to increase the char yield. Lignin torrefaction was carried out by pelletizing the lignin powder to produce discs of $25 \mathrm{~mm}$ in diameter using approximately $4 \mathrm{~g}$ of lignin. These lignin discs were placed inside a ceramic boat and the boat was 
introduced in the quartz tube reactor of a horizontal tube furnace. Heating rates of $3{ }^{\circ} \mathrm{C} / \mathrm{min}$ and $20^{\circ} \mathrm{C} / \mathrm{min}$ were used from room temperature to the final temperature. A constant flow of $\mathrm{N}_{2}$ at $100 \mathrm{ml} / \mathrm{min}$ was used throughout the test.

A high rank good coking coal and its coke were used as reference to evaluate the hydrochars obtained after hydrous pyrolysis of pristine lignin, torrefied lignin, their 50:50 wt.\%/wt.\% blend and the biocokes produced from the carbonization of the hydrochars.

\subsection{Hydrous pyrolysis and carbonization tests}

The equipment used for hydrous pyrolysis comprised of a Parr 4740 series stainless steel 75 $\mathrm{ml}$ cylindrical pressure vessel connected to a pressure gauge rated to 690 bars. Heat was applied by means of a fluidized sand bath, which was controlled by an external temperature controller. The temperature was monitored by means of an additional K-type thermocouple connected externally to a computer that records the temperature every 10 seconds. Each hydrous pyrolysis experiment was conducted on $6 \mathrm{~g}$ of pristine lignin using different temperatures, residence times and water contents. In addition, pristine lignin, torrefied lignin $\left(300{ }^{\circ} \mathrm{C}, 1\right.$ hour, $3^{\circ} \mathrm{C} / \mathrm{min}$ ) and their $50: 50 \mathrm{wt}$./wt. blend were hydrous pyrolysed at $350{ }^{\circ} \mathrm{C}$ for 6 hours using $30 \mathrm{ml}$ of water to prepare hydrochars for carbonization tests. In this case, the amount of pristine lignin used for each test was $15 \mathrm{~g}$ whereas the amount of torrefied lignin and the 50:50 wt./wt. blend was $18 \mathrm{~g}$. In all experiments performed, the reactor was flushed with nitrogen gas to reduce the oxygen content in the system. Afterwards, 2 bars pressure of $\mathrm{N}_{2}$ was pumped into the system to keep it inert throughout the experiment. The sand bath, which was connected to an external temperature controller and compressed air source, was pre-heated to the required temperature and left to equilibrate. The pressure vessel was then lowered onto the sand bath and the experiment left to run with a constant air flow through the sand bath. At the end of the experiment, the reactor was removed from the sand bath and allowed to cool to room temperature. To recover the residues or hydrochars, the reactor including the pressure gauge was first disconnected from the experimental set up and transferred to a fume cupboard where the generated gas was released. This was followed by dismantling the reactor, after which the hydrochar was transferred to a vacuum oven and dried for 3-4 hours at $40{ }^{\circ} \mathrm{C}$.

Carbonization tests were carried out in a sole heated oven. For each test, a sample of $80 \mathrm{~g}$ with particles $<1 \mathrm{~mm}$ was compacted in a stainless steel crucible, which was covered with a perforated ceramic top to allow the release of volatiles. The sole in the oven was pre-heated to $1050{ }^{\circ} \mathrm{C}$ and then the stainless steel crucible configuration containing the sample was placed inside the oven. The sample was heated from the sole at $1050{ }^{\circ} \mathrm{C}$ for 4 hours. The test was carried out in inert atmosphere as the volatiles generated by the sample impeded the contact with air.

\subsection{Proximate, ultimate and inorganic matter analyses}

Proximate analysis was carried out following the standard ISO 562 and ISO 1171 procedures for humidity, ash and volatile matter determination. For ultimate analysis, the standard procedures ASTM D5016-98 and ASTM D5373-02 were used for the determination of C, H $\mathrm{N}$ and S using LECO CHN-2000 and LECO S-144 DR instruments. The inorganic matter composition of each sample was analyzed by X-ray fluorescence (XRF) in a SRS 3000 Bruker spectrometer in accordance with the ASTM D4326-04 standard procedure. The alkalinity indexes for lignin, torrefied lignin and the coking coal were calculated using Eq. 1. This index gives an indication of the reactivity of the material whereby the higher the index the higher the reactivity and the less suitable for blast furnace operation [13]. 
Alkalinity index $(\%)=\frac{\left[\mathrm{Fe}_{2} \mathrm{O}_{3}\right]+[\mathrm{CaO}]+[\mathrm{MgO}]+\left[\mathrm{K}_{2} \mathrm{O}\right]+\left[\mathrm{Na}_{2} \mathrm{O}\right]}{\left[\mathrm{SiO}_{2}\right]+\left[\mathrm{Al}_{2} \mathrm{O}_{3}\right]} \times$ Ash $(\%)$

\section{4. $C P / M A S$ and SPE/MAS solid-state ${ }^{13} C$ nuclear magnetic resonance (NMR)}

Cross polarization (CP) and single pulse excitation (SPE) coupled with magic angle spinning (MAS) solid-state ${ }^{13} \mathrm{C}$ NMR analyses were performed in a Bruker Avance 200 spectrometer at a field strength of 4.7 Tesla corresponding to $50 \mathrm{MHz}$ for ${ }^{13} \mathrm{C}$ and $200 \mathrm{MHz}$ for ${ }^{1} \mathrm{H}$. $\mathrm{CP} / \mathrm{MAS}$ analyses were performed with pristine lignin, torrefied lignin $\left(300^{\circ} \mathrm{C}, 1\right.$ hour, 3

${ }^{\circ} \mathrm{C} / \mathrm{min}$ ) and three hydrochars obtained from pristine lignin at $240{ }^{\circ} \mathrm{C}, 280^{\circ} \mathrm{C}$ and $320^{\circ} \mathrm{C}$ for 1 hour using $20 \mathrm{ml}$ of water. SPE/MAS analyses were carried out with the hydrochars obtained from pristine lignin and torrefied lignin after hydrous pyrolysis at $350{ }^{\circ} \mathrm{C}$ for 6 hours using $30 \mathrm{ml}$ of water. Samples were packed tightly into a zirconia rotor with a Kel-F rotor-

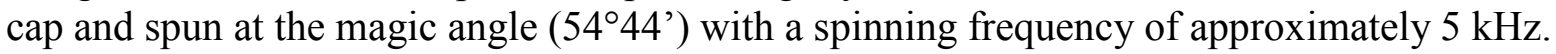
A contact time of 1 millisecond was used during the Hartmann-Hahn condition. The acquisition times in CP/MAS and SPE/MAS analyses were 1.5 seconds and 30 seconds, respectively. In both cases, the spectra were obtained after 2500 scans and the FIDs were processed using a line broadening factor of $50 \mathrm{~Hz}$. Tetrakis(trimethylsilyl)silane (TKS) was used as an internal standard to calibrate the position of the peaks.

\subsection{Thermal gravimetric analysis (TGA)}

TG/DTG analyses of the raw materials were carried out using a TA Instruments SDT 2960 thermoanalyser. $10-15 \mathrm{mg}$ of samples with particle sizes $<0.212 \mathrm{~mm}$ were heated to $1000{ }^{\circ} \mathrm{C}$ at a rate of $10{ }^{\circ} \mathrm{C} / \mathrm{min}$ under a $\mathrm{N}_{2}$ flow of $100 \mathrm{ml} / \mathrm{min}$. From the data obtained, the volatile matter evolved up to a specific temperature (VMT) and the derivative of the weight loss (DTG) curve were calculated. The temperature of maximum volatile matter evolution $\left(\mathrm{T}_{\max }\right)$ was also obtained from the TG/DTG curves.

\subsection{High-temperature $S A O S$ rheometry}

High-temperature small-amplitude oscillatory shear (SAOS) measurements were performed using a Rheometrics RDA-III high-torque controlled-strain rheometer. The amount of material used for each analysis was $1.5 \mathrm{~g}$. The samples were compacted with a hydraulic press under 5 tons of force to form discs of $25 \mathrm{~mm}$ in diameter. The tests involved placing the sample disc between two $25 \mathrm{~mm}$ parallel plates which had serrated surfaces to reduce slippage. The pine Kraft lignin, torrefied lignin $\left(300{ }^{\circ} \mathrm{C}, 1\right.$ hour, $\left.3{ }^{\circ} \mathrm{C} / \mathrm{min}\right)$, their blends and the hydrochar obtained from pristine lignin at $350^{\circ} \mathrm{C}$ for 6 hours and using $30 \mathrm{ml}$ of water were heated from $50{ }^{\circ} \mathrm{C}$ to $500{ }^{\circ} \mathrm{C}$ at $3{ }^{\circ} \mathrm{C} / \mathrm{min}$. The high rank good coking coal was heated from room temperature to $330^{\circ} \mathrm{C}$ at $85^{\circ} \mathrm{C} / \mathrm{min}$ and from $330{ }^{\circ} \mathrm{C}$ to $500{ }^{\circ} \mathrm{C}$ at $3{ }^{\circ} \mathrm{C} / \mathrm{min}$. The furnace surrounding the sample was purged with a constant flow of $\mathrm{N}_{2}$ to transfer heat to the sample and remove volatiles. The sample temperature was monitored using a thermocouple inside the furnace. A continuous sinusoidal varying strain with amplitude of $0.1 \%$ and frequency of $1 \mathrm{~Hz}(6.28 \mathrm{rad} / \mathrm{s})$ was applied to the sample from the bottom plate throughout the heating period. The stress response on the top plate was measured to obtain the complex viscosity $\left(\eta^{*}\right)$, which measures the resistance to deformation and flow of the material. The complex viscosity is calculated using Eq. 2, where $G^{\prime}$ is the storage or elastic modulus, $G^{\prime \prime}$ is the loss or viscous modulus and $\omega$ is the frequency [19]. 
$\eta^{*}($ Pa.s $)=\frac{\sqrt{\left\{\mathrm{G}^{\prime}(\mathrm{Pa})\right\}^{2}+\left\{\mathrm{G}^{\prime \prime}(\mathrm{Pa})\right\}^{2}}}{\omega\left(\mathrm{s}^{-1}\right)}$

\subsection{Diffuse reflectance infrared Fourier transform spectroscopy (DRIFTS)}

DRIFTS spectra were measured using a Nicolet Magna-IR560 spectrometer with a diffuse reflectance accessory. A mercury-cadmium-telluride array detector (MCT-A) that operates at sub-ambient temperature was used. Pristine lignin, lignin torrefied $\left(300{ }^{\circ} \mathrm{C}, 1\right.$ hour, 3 ${ }^{\circ} \mathrm{C} / \mathrm{min}$ ) and the hydrochars obtained from pristine lignin, torrefied lignin and their 50:50 wt. $\% /$ wt. $\%$ blend after hydrous pyrolysis at $350{ }^{\circ} \mathrm{C}$ for 6 hours using $30 \mathrm{ml}$ of water were analyzed. The samples were dried overnight before analysis and the data were collected in the range between $650-4000 \mathrm{~cm}^{-1}$ at a resolution of $4 \mathrm{~cm}^{-1}$.

\subsection{Field emission scanning electron microscopy}

Field emission scanning electron microscopy (FE-SEM) images were obtained on a Quanta FEG650 microscope (FEI Company) at $25 \mathrm{kV}$.

\subsection{Micro-strength and reactivity of biocokes/coke}

The micro-strength of biocokes and coke was determined by the method used by Ragan and Marsh [20]. Briefly, two charges of biocoke or coke (2 g, particle sizes 0.60-1.18 mm) were placed into two separate cylinders of $25.4 \mathrm{~mm}$ internal diameter and $305 \mathrm{~mm}$ length and sealed by steel dust caps. Each cylinder contained 12 steel ball-bearings of $8 \mathrm{~mm}$ in diameter. The samples were subjected to 800 rotations at a speed of $25 \mathrm{rpm}$. Three indices were derived after sieving: $R_{1}(>0.6 \mathrm{~mm}), R_{2}(0.6-0.212 \mathrm{~mm})$ and $R_{3}(<0.212 \mathrm{~mm})$. The higher the value of $\mathrm{R}_{1}$ (or the lower $\mathrm{R}_{3}$ ), the higher the micro-strength of the biocoke or coke. At least duplicate tests were performed on each sample.

The reactivity was measured following the ECE-INCAR method [21], which briefly consists on subjecting $7 \mathrm{~g}$ of biocoke/coke of particle sizes between 1-3 $\mathrm{mm}$ to a $\mathrm{CO}_{2}$ flow of 120 $\mathrm{ml} / \mathrm{min}$ at $1000^{\circ} \mathrm{C}$. The reactivity is expressed as the mass loss after 1 hour of reaction.

\subsection{Porosity and surface area determination}

In order to determine the microporous structure of the biocokes and coke, physical adsorption of $\mathrm{CO}_{2}$ at $0{ }^{\circ} \mathrm{C}(273 \mathrm{~K})$ was carried out in a Nova 4200e Quantachrome Instruments. Degassing was performed in vacuum for 24 hours at $200{ }^{\circ} \mathrm{C}$ prior to adsorption. The Dubinin-Radushkevich equation was applied to the $\mathrm{CO}_{2}$ adsorption isotherms in order to obtain the volume of micropores $\left(\mathrm{W}_{0}\right)$ and the characteristic adsorption energy $\left(\mathrm{E}_{0}\right)$. Following the procedure of Stoeckli [22], $\mathrm{E}_{0}$ was related to the average width of the micropores $(\mathrm{L})$ and $\mathrm{W}_{0}$ was related to the surface area of the micropores $\left(\mathrm{S}_{\mathrm{mi}}\right)$ by means of the following empirical equations:

$$
\begin{aligned}
& \mathrm{L}(\mathrm{nm})=\frac{10.8}{\mathrm{E}_{0}(\mathrm{~kJ} / \mathrm{mol})-11.4} \\
& \mathrm{~S}_{\mathrm{mi}}\left(\mathrm{m}^{2} / \mathrm{g}\right)=\frac{2000 \times \mathrm{W}_{0}\left(\mathrm{~cm}^{3} / \mathrm{g}\right)}{\mathrm{L}(\mathrm{nm})}
\end{aligned}
$$


The true density $\left(\rho_{\mathrm{He}}\right)$ of the biocokes and coke was measured by means of helium picnometry on a Micromeritics Accupyc 1330 Pycnometer. Their apparent density $\left(\rho_{\mathrm{Hg}}\right)$ was determined using mercury at $0.1 \mathrm{MPa}$ on a Micromeritics autopore IV 9500 mercury porosimeter. The open porosity corresponding to pore sizes $<12 \mu \mathrm{m}(\varepsilon)$ was calculated using the true and apparent densities by means of the following equation:

$\varepsilon(\%)=\left\{1-\frac{\rho_{\mathrm{Hg}}\left(\mathrm{g} / \mathrm{cm}^{3}\right)}{\rho_{\mathrm{He}}\left(\mathrm{g} / \mathrm{cm}^{3}\right)}\right\} \times 100$

The total pore volume $\left(\mathrm{V}_{\mathrm{T}}\right)$ was obtained from the equation:

$\mathrm{V}_{\mathrm{T}}\left(\mathrm{cm}^{3} / \mathrm{g}\right)=\left(\frac{1}{\rho_{\mathrm{Hg}}\left(\mathrm{g} / \mathrm{cm}^{3}\right)}-\frac{1}{\rho_{\mathrm{He}}\left(\mathrm{g} / \mathrm{cm}^{3}\right)}\right)$

The pore size distribution was calculated by applying increasing pressure to the sample from 0.1 to $227 \mathrm{MPa}$. This resulted in pore sizes in a range of $12 \mu \mathrm{m}$ to $5.5 \mathrm{~nm}$ in diameter (dp) according to the Washburn equation. Pore sizes were classified into three categories: macropores $(12 \mu \mathrm{m}>\mathrm{dp}>50 \mathrm{~nm})$, mesopores $(50 \mathrm{~nm}>\mathrm{dp}>5.5 \mathrm{~nm})$ and micropores $(\mathrm{dp}<5.5$ $\mathrm{nm})$.

\section{Results and discussion}

\subsection{Characterization of pristine and torrefied lignins}

The ash yield, volatile matter yield and elemental composition of the pristine pine Kraft lignin (PKL), the lignin torrefied at $300{ }^{\circ} \mathrm{C}$ for 1 hour using a heating rate of $3{ }^{\circ} \mathrm{C} / \mathrm{min}$ (TL) and the high rank good coking coal are presented in Table 1. Lignin torrefaction increases the ash yield from $2.5 \mathrm{wt} \%$ to $3.1 \mathrm{wt} \%$. The volatile matter yield and oxygen content of torrefied lignin are reduced from $64 \mathrm{wt} \%$ and $19 \mathrm{wt} \%$ to around $39 \mathrm{wt} \%$ and $26 \mathrm{wt} \%$ respectively, but they are still significantly higher than those of the high rank coal (23 wt $\%$ and $4 \mathrm{wt} \%)$.

The composition of the mineral matter and alkalinity index for the pristine lignin, torrefied lignin and high rank good coking coal are displayed in Table 2. The amounts of $\mathrm{SiO}_{2}$ and $\mathrm{Al}_{2} \mathrm{O}_{3}$ in the pristine and torrefied lignins (3\% and $1.2 \%$, respectively) are much lower than those in the good coking coal $(61 \%$ and $32 \%)$. On the contrary, the concentrations of $\mathrm{K}_{2} \mathrm{O}$ $(5-6 \%)$ and especially $\mathrm{Na}_{2} \mathrm{O}(35-39 \%)$ in pristine and torrefied lignins are much higher than those in the coal $(0.8 \%$ and $0.4 \%)$. As a result, the alkalinity indexes calculated with Eq. 1 for the pristine and torrefied lignins are much higher than that for the good coking coal $(>27 \% \mathrm{cf} .0 .6 \%)$. These results suggest that pristine and torrefied lignins are highly reactive and unsuitable for cokemaking in their current form.

The solid-state $\mathrm{CP} / \mathrm{MAS}{ }^{13} \mathrm{C}$ NMR spectra of the pristine lignin and lignin torrefied at $300{ }^{\circ} \mathrm{C}$ for 1 hour using a heating rate of $3{ }^{\circ} \mathrm{C} / \mathrm{min}$ are presented in Fig. 1. Table 3 presents the chemical shift assignments for the ${ }^{13} \mathrm{C}$ NMR peaks in lignin obtained from the literature $[24,25]$. The peak at $3.5 \mathrm{ppm}$ in the spectrum of torrefied lignin corresponds to the internal standard TKS. The spectra indicate that torrefaction removes aliphatic $\mathrm{C}-\mathrm{C}$ groups (around $33 \mathrm{ppm}$ ), polysaccharides (72 ppm), $\mathrm{C}-\mathrm{O}$ carbons including methoxyl carbons (56 ppm, 74 
ppm and $84 \mathrm{ppm})$ and carbonyl and carboxylic acid structures (180 ppm) and reduces significantly the amount of guaiacyl units as indicated by the reduction in the intensity of the peaks positioned at $115 \mathrm{ppm}$ and $148 \mathrm{ppm}$.

The DRIFTS spectra of these two samples are shown in Fig. 2. Aliphatic $\mathrm{C}-\mathrm{H}$ appears in the region $3000-2800 \mathrm{~cm}^{-1}, \mathrm{C}=\mathrm{O}$ groups produce a peak at $1700 \mathrm{~cm}^{-1}$, aromatic rings produce peaks at around $1600,1510,1465$ and $1430 \mathrm{~cm}^{-1}$, syringyl groups produce a peak at 1370 $\mathrm{cm}^{-1}$, guaiacyl groups produce a peak at $1270 \mathrm{~cm}^{-1}$ and $\mathrm{C}-\mathrm{O}$ from methoxy groups appears at $1120-1050 \mathrm{~cm}^{-1}[26,27]$. Torrefaction causes a reduction in all the peaks in the region $1600-900 \mathrm{~cm}^{-1}$. Therefore, aromatic rings, guaiacyl groups and methoxy groups are the most affected and seem to confirm aforementioned findings from solid-state ${ }^{13} \mathrm{C}$ NMR.

The viscoelastic properties as a function of temperature of the pine Kraft lignin (i.e. pristine), torrefied lignin and the high rank coal were determined (Fig. 3). Pine Kraft lignin presents two minima in complex viscosity at around $220^{\circ} \mathrm{C}$ and $340^{\circ} \mathrm{C}$. Torrefaction of lignin at 300 ${ }^{\circ} \mathrm{C}$ destroys the fluid components evolving at $220{ }^{\circ} \mathrm{C}$ whereas the fluid components evolving at $340{ }^{\circ} \mathrm{C}$ are still present. It could be argued that the fluid entities forming at $220^{\circ} \mathrm{C}$ in pine Kraft lignin could mainly derive from the decomposition of $\mathrm{C}-\mathrm{C}$, polysaccharides, $\mathrm{C}-\mathrm{O}$, carbonyl and carboxylic acid structures identified by $\mathrm{CP} / \mathrm{MAS}{ }^{13} \mathrm{C}$ NMR and DRIFTS. Torrefaction is not able to increase the maturation of lignin as indicated by the overlapping of the complex viscosity curves during resolidification. The good coking coal presents a minimum in complex viscosity at around $460{ }^{\circ} \mathrm{C}$, which is $130{ }^{\circ} \mathrm{C}$ higher than that of torrefied lignin. The thermoplastic temperature range of the coal is much narrower $\left(75^{\circ} \mathrm{C}\right)$ that that of pristine lignin $\left(220^{\circ} \mathrm{C}\right)$, which is clear evidence of the different chemical properties of the fluid entities in these materials.

The effects of torrefaction temperature and heating rate on the viscoelastic properties of lignin were also evaluated. Table 4 presents the minimum complex viscosity $\left(\eta^{*}{ }_{\min }\right)$ and temperature of minimum complex viscosity or maximum fluidity $\left(\mathrm{T}_{\mathrm{mf}}\right)$ for the high rank coal, pristine pine Kraft lignin and the lignin torrefied at $250{ }^{\circ} \mathrm{C}$ and $300^{\circ} \mathrm{C}$ using a heating rate of $3{ }^{\circ} \mathrm{C} / \mathrm{min}$ and at $300^{\circ} \mathrm{C}$ using a heating rate of $20^{\circ} \mathrm{C} / \mathrm{min}$. An increase in torrefaction temperature causes an increase in the minimum complex viscosity (i.e. decrease in fluidity) and an increase in the temperature of maximum fluidity due to the partial disappearance of the peak at $220{ }^{\circ} \mathrm{C}$. An increase in heating rate from $3{ }^{\circ} \mathrm{C} / \mathrm{min}$ to $20^{\circ} \mathrm{C} / \mathrm{min}$ increases fluidity development and decreases slightly the temperature of maximum fluidity by around $7^{\circ} \mathrm{C}$. The temperature of maximum fluidity of the sample torrefied at $300{ }^{\circ} \mathrm{C}$ using a heating rate of $3{ }^{\circ} \mathrm{C} / \mathrm{min}\left(328^{\circ} \mathrm{C}\right)$ is the closest to that of the high rank coal $\left(462^{\circ} \mathrm{C}\right)$ and for this reason was selected for further testing.

Blends of pristine lignin and lignin torrefied at $300{ }^{\circ} \mathrm{C}$ for 1 hour using a heating rate of 3 ${ }^{\circ} \mathrm{C} /$ min were prepared and their viscoelastic behaviors were also determined (Figs. 3 and 4). The results indicate that the viscoelastic behavior of the blends shifts from the viscoelastic behavior of pristine lignin to that of torrefied lignin as the amount of torrefied lignin in the blend increases. Those blends that contain pristine lignin in percentages between 30-60 wt. \% show very similar viscoelastic behaviors, which are characterized by minimum complex viscosity values in the order of $1.5 \times 10^{5}-3.0 \times 10^{5} \mathrm{~Pa}$.s between $200-325^{\circ} \mathrm{C}$. It was observed that the chars obtained at $500{ }^{\circ} \mathrm{C}$ from these blends possessed good mechanical strength, and thus, a 50:50 wt.\%/wt.\% blend was selected for hydrous pyrolysis tests in order to elucidate possible synergistic effects between the components. 


\subsection{Characterization of hydrous pyrolysis residues from pine Kraft lignin}

The effect of hydrous pyrolysis temperature on the viscoelastic behavior of pine Kraft lignin was investigated. Fig. 5 shows the viscoelastic behavior of the hydrous pyrolysis residues (or hydrochars) obtained at temperatures ranging from $220^{\circ} \mathrm{C}$ to $320^{\circ} \mathrm{C}$. The viscoelastic behavior of pristine pine Kraft lignin is also shown for comparison purposes. The scattering of data in the plot might be attributable to the release of gaseous products that cause force fluctuations on the rheometer's transducer. The results indicate that the amount of fluid material in the hydrochars decreases with hydrous pyrolysis temperature in the order: $300{ }^{\circ} \mathrm{C}$ $>280{ }^{\circ} \mathrm{C}>220{ }^{\circ} \mathrm{C}>240{ }^{\circ} \mathrm{C}>310{ }^{\circ} \mathrm{C}>320{ }^{\circ} \mathrm{C}$. The highest amount of fluid material is obtained with the hydrochar produced at $300{ }^{\circ} \mathrm{C}$ and this sample also yields the widest thermoplastic temperature range $\left(150-350^{\circ} \mathrm{C}\right)$. The DTG profiles of the hydrochars obtained at $240{ }^{\circ} \mathrm{C}, 280{ }^{\circ} \mathrm{C}$ and $320^{\circ} \mathrm{C}$ indicate that lignin undergoes major degradation at temperatures above $280^{\circ} \mathrm{C}$ (Fig. 6). All these results suggest that hydrous pyrolysis of lignin at $280-300{ }^{\circ} \mathrm{C}$ promotes the formation of liquid entities as suggested by the high fluidity of the hydrochars at these temperatures compared to the fluidity of hydrochars produced at 220 $240{ }^{\circ} \mathrm{C}$. However, these fluid entities seem to convert into gaseous products and/or form precipitates by condensation reactions at hydrous pyrolysis temperatures $>300{ }^{\circ} \mathrm{C}$, which leads to the drastic reduction in hydrochar fluidity.

The solid-state CP/MAS ${ }^{13} \mathrm{C}$ NMR results for pristine pine Kraft lignin (Fig. 1) and the hydrochars obtained at $240{ }^{\circ} \mathrm{C}, 280^{\circ} \mathrm{C}$ and $320^{\circ} \mathrm{C}$ (Fig. 7) indicate that hydrous pyrolysis removes the peaks at around $33 \mathrm{ppm}$ (aliphatic $\mathrm{C}-\mathrm{C}$ groups), at 70-90 ppm (polysaccharides and aliphatic $\mathrm{C}-\mathrm{O}$ carbons) and at around $180 \mathrm{ppm}$ (carbonyl and carboxylic acid structures). These results indicate that hydrous pyrolysis causes similar structural modifications in lignin to those caused by torrefaction. Indeed, the spectrum of the hydrous pyrolysed lignin at 280 ${ }^{\circ} \mathrm{C}$ resembles that of torrefied lignin at $300{ }^{\circ} \mathrm{C}$ (Fig. 1). The spectra of the hydrochars obtained at $240{ }^{\circ} \mathrm{C}$ and $280{ }^{\circ} \mathrm{C}$ are fairly similar but different to the spectrum of the hydrochar obtained at $320^{\circ} \mathrm{C}$. These results indicate that there is significant reduction in methoxyl groups (56 ppm) and C-3 and C-4 carbons of guaiacyl units $(148 \mathrm{ppm})$ at $320^{\circ} \mathrm{C}$, which could be mainly responsible for the reduction in hydrochar fluidity (Fig. 5) and the reduction in the maximum rate of volatile release observed in the DTG plots (Fig. 6).

The effect of hydrous pyrolysis time on the viscoelastic properties of the hydrochars is presented in Fig. 8. An increase in residence time causes a reduction in fluidity development. The hydrochar obtained after hydrous pyrolysis at $300{ }^{\circ} \mathrm{C}$ for 30 minutes and using $20 \mathrm{ml}$ of water develops the same minimum in complex viscosity as the pristine lignin (ca. $10^{3}$ Pa.s) but the temperature of maximum fluidity is approximately $50{ }^{\circ} \mathrm{C}$ higher. An increase in residence time from 30 minutes to 1 hour leads to a significant increase in the minimum complex viscosity from around $10^{3} \mathrm{~Pa}$.s to $3 \times 10^{3} \mathrm{~Pa}$.s with the simultaneous increase in the temperature of maximum fluidity from $270{ }^{\circ} \mathrm{C}$ to $285^{\circ} \mathrm{C}$. A residence time of 2 hours almost completely destroys fluidity development (minimum complex viscosity of $3.2 \times 10^{4} \mathrm{~Pa} . \mathrm{s}$ ) and causes a further increase in the temperature of maximum fluidity to $290{ }^{\circ} \mathrm{C}$. These results suggest that short residence times of less than an hour should be used to preserve the fluid material in the hydrochar whereas residence times $>2$ hours would be required to produce a hydrochar that resembles a semi-coke from coking coal.

The effect caused on the viscoelastic properties of the hydrochar by the amount of water used during lignin hydrous pyrolysis is presented in Fig. 9. The amount of fluid material in the hydrochar decreases with the amount of water in the order: $20 \mathrm{ml}>5 \mathrm{ml} \approx 10 \mathrm{ml}>30 \mathrm{ml}>$ 
$15 \mathrm{ml}>$ anhydrous. Based on previous research, it has been suggested that the ratio of water to biomass should be kept as low as possible to enhance polymerization [28]. Indeed, more liquid product was produced during hydrous pyrolysis of an immature Kimmeridge Clay source rock at $310^{\circ} \mathrm{C}$ for 7 hours by increasing the water content [29], and it was found that the liquid yield increased with the amount of water in the system up to $20 \mathrm{ml}$ when using $4 \mathrm{~g}$ of Kimmeridge Clay source rock (i.e. water to source rock ratio of 5:1) but it decreased with higher amounts of water. Analogously, the viscoelastic behaviors of the hydrochars obtained after hydrous pyrolysis of $6 \mathrm{~g}$ of lignin at $300{ }^{\circ} \mathrm{C}$ indicate that the water to lignin ratio required to promote maximum fluidity development is close to $3.3: 1$.

In summary, maximum fluidity (or minimum complex viscosity) in the hydrochar was obtained at hydrous pyrolysis temperatures of $280-300{ }^{\circ} \mathrm{C}$ with $20 \mathrm{ml}$ of water and residence times of 30 minutes. However, none of the hydrous pyrolysis conditions studied was able to increase lignin maturation (i.e. cross-linking condensation of aromatic rings) as indicated by the almost perfect overlapping of the complex viscosity curves of the hydrochars during resolidification. This implies that pristine pine Kraft lignin cannot be converted into a coking coal-like material using the hydrous pyrolysis conditions studied herein.

\subsection{Comparison of hydrochars from pristine lignin, torrefied lignin and their blend}

A different approach focused on the modification of lignin through torrefaction prior to hydrous pyrolysis in order to improve its coking properties. Furthermore, the hydrous pyrolysis temperature, the residence time and the water content were increased to $350{ }^{\circ} \mathrm{C}, 6$ hours and $30 \mathrm{ml}$ respectively in order to produce a high carbon content material with no fluidity comparable to a semi-coke from coking coal. In this manner, hydrochars were produced from pristine pine Kraft lignin, lignin torrefied at $300{ }^{\circ} \mathrm{C}$ for 1 hour using a heating rate of $3{ }^{\circ} \mathrm{C} / \mathrm{min}$, and a $50: 50 \mathrm{wt} . \% / \mathrm{wt} . \%$ blend of these pristine and torrefied lignins. Table 1 summarizes the results from proximate and ultimate analyses. A comparison of the results for the hydrochars with those for the pristine pine Kraft lignin indicates that hydrous pyrolysis lowers the ash content from $2.5 \mathrm{wt} . \%$ to $1.0 \mathrm{wt} . \%$. The ash content in the hydrochar obtained from torrefied lignin $(1.7 \mathrm{wt} . \%)$ is also lower than that in pine Kraft lignin but higher than the ash content in the hydrochar from pristine lignin, showing that torrefaction prevents the transfer of mineral matter to the aqueous phase during hydrous pyrolysis. The hydrochar from the 50:50 wt.\%/wt.\% blend has similar ash content to that in the hydrochar from torrefied lignin, suggesting that there could be synergistic effects between the pristine and torrefied lignin components during hydrous pyrolysis. All three hydrochars produce ash yields $<2 \mathrm{wt} . \%$, which are lower than that obtained with the good coking coal (10 wt.\%) and could be beneficial for biocoke quality. However, it has to be noted that the alkalinity indexes of lignin and torrefied lignin are much higher than that of coking coal (Table 2). Unfortunately, metal contamination was observed during the characterization of the mineral matter in the hydrochars. Future work should focus on this task and also on the use of acid washing with the hydrochars in order to remove the catalytic alkali/alkaline earth metals and determine the extent of reactivity of the inherent char structure.

On the other hand, the volatile matter content of the hydrochar from torrefied lignin $(25.8$ wt.\%) is similar to that of a medium rank coking coal whereas the volatile matter content of the hydrochar from lignin (31.2 wt.\%) is similar to that of a low rank coking coal. The carbon content of all hydrochars is similar and comparable to that of the high rank coking coal (ca. $80 \mathrm{wt} . \%$ ). Hydrous pyrolysis reduces the sulfur content in pristine lignin from 1.5 wt. $\%$ to $<1.0 \mathrm{wt} . \%$ and the oxygen content from around $26 \mathrm{wt} . \%$ to $12 \mathrm{wt} . \%$. However, the 
oxygen contents in the three hydrochars $(>11 \mathrm{wt} . \%)$ are much higher than that in the good coking coal (3.6 wt.\%), which could result in a biocoke excessively reactive for blast furnace operation.

Table 5 presents the mean hydrochar yields obtained after carrying out several hydrous pyrolysis tests. As expected, the hydrochar yield increases by $24 \%$ after lignin torrefaction. The hydrochar yield from the 50:50 wt.\%/wt.\% blend (77\%) is higher than that calculated from the individual components $(73 \%)$, which is significant taking into account the standard deviation values obtained for the mean yields, and could be related to synergistic effects and/or mass diffusion limitations as the samples were hydrous pyrolysed in pellet form.

High-temperature rheometry testing of the hydrochar obtained from pristine pine Kraft lignin indicated that the material did not develop any fluid material (not shown). From these results and considering that pristine lignin develops more fluidity than torrefied lignin or the 50:50 wt.\%/wt.\% blend, it can be inferred that none of the hydrochars develop a fluid phase upon heating.

TGA/DTG profiles for the hydrochars and the high rank good coking coal are shown in Fig. 6. The three hydrochars present very similar patterns of volatile matter evolution but these are quite different from that of the good coking coal. The data presented in Table 6 indicate that the percentage of volatile matter evolving from the hydrochars at temperatures $<400{ }^{\circ} \mathrm{C}$ is much higher than that evolving from the high rank coal. The opposite occurs between $400-500{ }^{\circ} \mathrm{C}$ with no significant changes in the percentage of volatile matter of the samples at temperatures between $500-700{ }^{\circ} \mathrm{C}$. The hydrochars show three maxima in the rate of volatile matter evolution whereas the high rank coal only shows one maximum at $486{ }^{\circ} \mathrm{C}$. Table 5 shows that the highest biocoke/coke yield as determined by thermogravimetric analysis is produced by the coal (77\%), followed by the hydrochar from torrefied lignin $(73 \%)$, the hydrochar from the blend (70\%) and the hydrochar from pristine lignin (67\%). Differing from hydrous pyrolysis tests results, the biocoke yield from the blend hydrochar can be calculated from the biocoke yields of the single hydrochars. This could be ascribed to the lack of diffusion limitations in thermogravimetric analysis due to testing of a small amount of sample (10-15 $\mathrm{mg})$ in powder form.

The SPE/MAS solid-state ${ }^{13} \mathrm{C}$ NMR spectra of the hydrochars obtained from pristine lignin (HL) and torrefied lignin (HTL) are presented in Fig. 7. Two spinning sidebands (ssb) originate from the aromatic carbon positioned at $130 \mathrm{ppm}$ and are positioned at equal distances of the aromatic peak (i.e. there is one spinning sideband positioned in the aliphatic region). The spectra show no significant differences in the aliphatic and aromatic carbon structures of the hydrochars. The DRIFTS spectra presented in Fig. 10 also suggest that there are not significant differences in the distribution of functional groups on the hydrochar surfaces. A comparison of the spectra from the hydrochars with that obtained from pristine lignin (Fig. 2) indicates that there are significant modifications in the lignin structure during hydrous pyrolysis. Similar results were observed by other authors with a dealkali lignin and the hydrochars obtained at $225-265^{\circ} \mathrm{C}$ [26]. However, the DRIFTS spectrum from torrefied lignin in Fig. 2 is very similar to the spectra from the three hydrochars in Fig. 10.

\subsection{Comparison of biocokes with coke}

Carbonization tests were performed with the hydrochars obtained after hydrous pyrolysis at $350{ }^{\circ} \mathrm{C}$ for 6 hours using $30 \mathrm{ml}$ of water from the pristine lignin, torrefied lignin and their 
50:50 wt./wt. blend. Coal carbonization was also carried out to compare the results from the coke with those from the hydrochars. The biocoke obtained from the torrefied lignin hydrochar did not show agglomeration and disintegrated into a powder. Considering that the hydrochars from the pristine and torrefied lignins have similar chemical compositions, as indicated above, this behavior is not well understood and needs further investigation. The biocoke obtained from the torrefied lignin hydrochar was not tested any further.

Table 1 present the data from proximate and ultimate analyses for the biocokes derived from the hydrochars of pristine lignin (HL) and the 50:50 wt.\%/wt.\% blend (HB) and for the coke from coal as reference. Although the biocokes from lignin and the blend yield very low amounts of ash (1.2-2.5 wt.\%) compared to the coke (16 wt.\%), their oxygen contents are very high (ca. 1.5 wt. $\%$ cf. 0.1 wt.\%).

The micro-strength results in Table 7 indicate that the biocokes possess very low cold mechanical strength compared to the coke. Indeed, the biocokes have values of $\mathrm{R}_{1}$ below $1 \%$ compared to $17 \%$ for the coke. The biocoke obtained from the blend hydrochar has lower strength than the biocoke from the lignin hydrochar as denoted by the higher value of $\mathrm{R}_{3}$ (74\% cf. 69\%). This finding was expected since the biocoke obtained from the torrefied lignin hydrochar did not agglomerate. Table 7 also shows that both biocokes possess very high reactivity $(>45 \%)$ compared to the coke $(10 \%)$ as determined by the ECE-INCAR method.

FE-SEM images of the hydrochar derived from pristine lignin, the biocokes from this hydrochar before and after the $\mathrm{CO}_{2}$ reactivity test and the coke from coal indicate that there are significant textural differences between the lignin residues and coke (Fig. 11). Coke presents a well-defined porous structure with a wider range of pore sizes than the porous structure of the hydrochar or biocokes. Table 8 indicates that the microporous surface area of the biocoke obtained from the lignin hydrochar is much higher than the microporous surface area in the coke $\left(414 \mathrm{~m}^{2} / \mathrm{g} \mathrm{cf} .145 \mathrm{~m}^{2} / \mathrm{g}\right)$. In addition, the total porosity of this biocoke is around $12 \%$ higher than that in the coke. This table also shows that the biocoke obtained from the blend hydrochar possesses higher porosity and microporous surface area than the biocoke obtained from the lignin hydrochar.

These results suggest that the poor mechanical strength and high reactivity of the biocokes could be ascribed to a combination of high porosity resulting in thin pore walls (i.e. brittle pore structures), high oxygen contents in the biocokes (ca. $1.5 \mathrm{wt} \%$ ) compared to the coke $(0.1 \mathrm{wt} . \%)$ and high alkali and alkaline earth metals contents in the hydrochars. Therefore, hydrochars from Kraft lignin from pine wood cannot be used in their pristine and/or torrefied forms for the complete substitution of coking coals but still could potentially be added to coking blends if the cohesion with coking coals is acceptable. Pre-treatment of the pine Kraft lignin with inexpensive acids should be investigated in the future as a possible methodology to improve the coking properties of lignin hydrochars and resulting biocokes.

\section{Conclusions}

Pine Kraft lignin in pristine and torrefied forms and their 50:50 wt.\%/wt.\% blend have been used to obtain and characterize hydrochars through hydrous pyrolysis. These hydrochars have been used to produce biocokes after carbonization at $1050{ }^{\circ} \mathrm{C}$. A high rank good coking coal and the coke obtained after carbonization have been used as reference materials to evaluate the properties of the hydrochars and biocokes, respectively. The highest fluidity in 
the lignin hydrochar was achieved when hydrous pyrolysis was carried out at $280-300{ }^{\circ} \mathrm{C}$ for short periods of time (30 minutes) and using $20 \mathrm{ml}$ of water. However, none of the conditions studied was able to increase the maturation of the hydrochar since resolidification occurred at the same temperature to that of the pristine lignin. These results indicate that lignin cannot be converted into a coking coal-like material through the hydrous pyrolysis conditions studied in this work.

Torrefaction causes significant changes in the chemical structure of lignin with the complete degradation of aliphatic $\mathrm{C}-\mathrm{C}$ and $\mathrm{C}-\mathrm{O}$ groups, polysaccharides, carbonyl and carboxylic acid structures, which are very similar to the modifications caused by lignin hydrous pyrolysis.

However, the biocoke produced from the hydrous pyrolysed torrefied lignin did not agglomerate in contrast to the biocoke resulting from a $50 \mathrm{wt} . \% / 50 \mathrm{wt} . \%$ blend of pristine and torrefied lignins. This anomalous behavior is not well understood and requires further investigation.

The hydrochars obtained at $350{ }^{\circ} \mathrm{C}$ for 6 hours using $30 \mathrm{ml}$ of water from pine Kraft lignin, torrefied lignin and the 50:50 wt.\%/wt.\% blend of pristine and torrefied lignins produce ash yields $<2 \mathrm{wt} . \%$ that are lower than that obtained with the good coking coal (10 wt.\%), which could be beneficial for biocoke quality. However, the reactivity of the resulting biocokes is excessively high compared to that of the good coking coal $(>45 \%$ cf. $10 \%)$ and the microstrength $R_{1}$ values of the biocokes are much lower than that of the coal $(<1 \% \mathrm{cf} .17 \%)$. These results could be explained by the high total porosity of the biocokes $(>39 \%)$ and their high microporous surface areas $\left(>400 \mathrm{~m}^{2} / \mathrm{g}\right)$ compared to those for the coal $\left(27 \%\right.$ and $\left.145 \mathrm{~m}^{2} / \mathrm{g}\right)$ and the high alkalinity indexes of pristine and torrefied lignins compared to that of coal (>27\% cf. 0.6\%).

These drawbacks need to be addressed in order to use pine Kraft lignin hydrochars for biocoke production and utilization in integrated steel plants. Therefore, further investigation would be required to determine whether the oxygen content and the amount of alkali/alkaline earth metals could be significantly reduced through economically viable Kraft lignin pretreatments (e.g. acid washing) in order to increase the strength and lower the reactivity of the resulting lignin hydrochars and biocokes.

\section{Acknowledgements}

The research leading to these results has received funding from the European Union's Research Programme of the Research Fund for Coal and Steel (RFCS) research programme under grant agreement No. [RFCR-CT-2014-00006]. The authors are also very grateful to MeadWestvaco for supplying the pine Kraft lignin.

\section{References}

[1] S. Das, S. Sharma, R. Choudhury, Non-coking coal to coke: use of biomass based blending material, Energy 27 (2002) 405-414.

[2] M.A. Diez, R. Alvarez, M. Fernández, Biomass derived products as modifiers of the rheological properties of coking coals, Fuel 96 (2012) 306-313.

[3] S. Kokonya, M. Castro-Díaz, C. Barriocanal, C.E. Snape, An investigation into the effect of fast heating on fluidity development and coke quality for blends of coal and biomass, Biomass and Bioenergy 56 (2013) 295-306. 
[4] R. Sakurovs, Some factors controlling the thermoplastic behaviour of coals, Fuel 79 (2000) 379-389.

[5] M. Castro-Díaz, H. Zhao, S. Kokonya, A. Dufour, C.E. Snape, The effect of biomass on fluidity development in coking blends using high-temperature SAOS rheometry, Energy and Fuels 26 (2012) 1767-1775.

[6] M.A. Diez, A.G. Borrego, Evaluation of $\mathrm{CO}_{2}$-reactivity patterns in cokes from coal and woody biomass blends, Fuel 113 (2013) 59-68.

[7] M.G. Montiano, E. Díaz-Faes, C. Barriocanal, R. Alvarez, Influence of biomass on metallurgical coke quality, Fuel 116 (2014) 175-182.

[8] M.G. Montiano, C. Barriocanal, R. Alvarez, Effect of the addition of waste sawdust on thermoplastic properties of a coal, Fuel 106 (2013) 537-543.

[9] M.G. Montiano, E. Díaz-Faes, C. Barriocanal, Partial briquetting vs direct addition of biomass in coking blends, Fuel 137 (2014) 313-320.

[10] M.G. Montiano, E. Díaz-Faes, C. Barriocanal, Effect of briquette composition and size on the quality of the resulting coke, Fuel Processing Technology 148 (2016) 155-162.

[11] Y. Ueki, Y. Nunome, R. Yoshiie, I. Naruse, Y. Nishibata, S. Aizawa, Effect of woody biomass addition on coke properties, ISIJ International 54 (2014) 2454-2460.

[12] T. Matsumura, M. Ichida, T. Nagasaka, K. Kato, Carbonization behaviour of woody biomass and resulting metallurgical coke properties, ISIJ International 48 (2008) 572-577. [13] K.W. Ng, J.A. MacPhee, L. Giroux, T. Todoschuk, Reactivity of bio-coke with $\mathrm{CO}_{2}$, Fuel Processing Technology 92 (2011) 801-804.

[14] J.A. MacPhee, J.F. Gransden, L. Goroux, J.T. Price, Possible $\mathrm{CO}_{2}$ mitigation via addition of charcoal to coking coal blends, Fuel Processing Technology 90 (2009) 16-20. [15] S. Kudo, A. Mori, R. Soejima, F. Murayama, S. Nomura, Y. Dohi, K. Norinaga, J.-I. Hayashi, Preparation of coke from hydrothermally treated biomass in sequence of hot briquetting and carbonization, ISIJ International 54 (2014) 2461-2469.

[16] G.W. Huber, S. Iborra, A. Corma, Synthesis of transportation fuels from biomass: Chemistry, catalysts and engineering, Chemical Reviews 106 (2006) 4044-4098.

[17] M.R. Lumadue, F.S. Cannon, N.R. Brown, Lignin as both fuel and fusing binder in briquetted anthracite fines for foundry coke substitute, Fuel 97 (2012) 869-875.

[18] J.-L. Wena, S.-L. Sun, T.-Q. Yuan, F. Xu, R.-C. Sun, Understanding the chemical and structural transformations of lignin macromolecule during torrefaction, Applied Energy 121 (2014) 1-9.

[19] K.M. Steel, M. Castro Díaz, J.W. Patrick, C.E. Snape, Use of rheometry and ${ }^{1}$ H NMR spectroscopy for understanding the mechanisms behind the generation of coking pressure, Energy and Fuels 18 (2004) 1250-1256.

[20] S. Ragan, H. Marsh, Carbonization and liquid-crystal (mesophase) development. 22. Micro-strength and optical textures of cokes from coal-pitch co-carbonizations, Fuel 60 (1981) 522-528.

[21] J.A. Menendez, R. Alvarez, J.J. Pis, Relationship between different methods of determination of coke reactivity (Spanish), Revista de Metalurgia 29 (1993) 214-222.

[22] F. Stoeckli, Characterization of microporous carbons by adsorption and immersion techniques, in: J.W. Patrick (Ed.), Porosity in carbons, Edward Arnold, London, 1995, pp. 67-92.

[23] R.K. Sharma, J.B. Wooten, V.L. Baliga, X. Lin, W.G. Chan, M.R. Hajaligol, Characterization of chars from pyrolysis of lignin, Fuel 83 (2004) 1469-1482.

[24] P.G. Hatcher, Chemical structural studies of natural lignin by dipolar dephasing solidstate ${ }^{13} \mathrm{C}$ nuclear magnetic resonance, Organic Geochemistry 11 (1987) 31-39. 
[25] Y. Li, D. Cui, Y. Tong, L. Xu, Study on structure and thermal stability properties of lignin during thermostabilization and carbonization, International Journal of Biological Macromolecules 62 (2013) 663-669.

[26] S. Kang, X. Li, J. Fan, J. Chang, Characterization of hydrochars produced by hydrothermal carbonization of lignin, cellulose, D-xylose, and wood meal, Industrial and Engineering Chemistry Research 51 (2012) 9023-9031.

[27] Q. Liu, S. Wang, Y. Zheng, Z. Luo, K. Cen, Mechanism study of wood lignin pyrolysis by using TG-FTIR analysis, Journal of Analytical and Applied Pyrolysis 82 (2008) 170-177. [28] A. Funke, F. Ziegler, Hydrothermal carbonization of biomass: A summary and discussion of chemical mechanisms for process engineering, Biofuels, Bioproducts and Biorefining 4 (2010) 160-177.

[29] A.D. Carr, C.E. Snape, W. Meredith, C. Uguna, I.C. Scotchman, R.C. Davis, The effect of water pressure on hydrocarbon generation reactions: some inferences from laboratory experiments, Petroleum Geoscience 15 (2009) 17-26. 
Table 1. Proximate and ultimate analyses of pristine pine Kraft lignin (PKL), torrefied lignin at $300{ }^{\circ} \mathrm{C}$ for 1 hour using a heating rate of $3{ }^{\circ} \mathrm{C} / \mathrm{min}$ (TL), hydrochars obtained at $350{ }^{\circ} \mathrm{C}$ for 6 hours using $30 \mathrm{ml}$ of water from pristine lignin (HL), torrefied lignin (HTL) and their 50:50 wt.\%/wt.\% blend (HB), biocokes from the lignin and blend hydrochars, high rank good coking coal and coke. Weight percentages expressed on a dry basis (db).

\begin{tabular}{lccccccc}
\hline & Ash & VM & $\mathrm{C}$ & $\mathrm{H}$ & $\mathrm{N}$ & $\mathrm{S}$ & $\mathrm{O}$ \\
& $(\%, \mathrm{db})$ & $(\%, \mathrm{db})$ & $(\%, \mathrm{db})$ & $(\%, \mathrm{db})$ & $(\%, \mathrm{db})$ & $(\%, \mathrm{db})$ & $(\%, \mathrm{db})$ \\
\hline PKL & 2.5 & 64.0 & 64.7 & 5.7 & 0.9 & 1.5 & 26.3 \\
HL & 1.0 & 31.2 & 82.0 & 4.6 & 1.1 & 0.8 & 11.5 \\
Biocoke (HL) & 1.2 & 1.1 & 96.7 & 0.6 & 1.5 & 0.5 & 1.4 \\
\hline TL & 3.1 & 38.7 & 73.5 & 4.8 & 0.7 & 1.1 & 19.0 \\
HTL & 1.7 & 25.8 & 81.6 & 4.1 & 0.9 & 0.9 & 12.5 \\
\hline HB & 1.7 & 28.8 & 82.5 & 4.5 & 0.9 & 0.9 & 11.2 \\
Biocoke (HB) & 2.5 & 1.7 & 94.7 & 0.4 & 1.2 & 0.8 & 1.6 \\
\hline Coal & 10.1 & 22.9 & 79.5 & 4.5 & 1.9 & 0.5 & 3.6 \\
Coke & 15.9 & 0.5 & 81.7 & 0.4 & 1.6 & 0.5 & 0.1 \\
\hline
\end{tabular}

Table 2. Mineral matter composition and alkalinity index of pristine pine Kraft lignin (PKL), lignin torrefied at $300{ }^{\circ} \mathrm{C}$ for 1 hour using a heating rate of $3{ }^{\circ} \mathrm{C} / \mathrm{min}$ (TL) and the high rank good coking coal.

\begin{tabular}{lcccccccc}
\hline & $\begin{array}{c}\mathrm{Fe}_{2} \mathrm{O}_{3} \\
(\%, \mathrm{db})\end{array}$ & $\begin{array}{c}\mathrm{CaO} \\
(\%, \mathrm{db})\end{array}$ & $\begin{array}{c}\mathrm{MgO} \\
(\%, \mathrm{db})\end{array}$ & $\begin{array}{c}\mathrm{K}_{2} \mathrm{O} \\
(\%, \mathrm{db})\end{array}$ & $\begin{array}{c}\mathrm{Na}_{2} \mathrm{O} \\
(\%, \mathrm{db})\end{array}$ & $\begin{array}{c}\mathrm{SiO}_{2} \\
(\%, \mathrm{db})\end{array}$ & $\begin{array}{c}\mathrm{Al}_{2} \mathrm{O}_{3} \\
(\%, \mathrm{db})\end{array}$ & $\begin{array}{c}\text { Alkalinity } \\
\text { index }(\%)\end{array}$ \\
\hline PKL & 0.3 & 1.0 & 1.0 & 4.7 & 38.5 & 3.0 & 1.2 & 27.1 \\
$\mathrm{TL}$ & 0.3 & 1.0 & 1.1 & 6.1 & 35.2 & 2.9 & 1.2 & 33.0 \\
Coal & 3.0 & 0.8 & 0.5 & 0.8 & 0.4 & 60.8 & 31.5 & 0.6 \\
\hline
\end{tabular}

Table 3. Solid-state ${ }^{13} \mathrm{C}$ NMR chemical shift assignments for lignin.

\begin{tabular}{ll}
\hline Band $(\mathrm{ppm})$ & Assignment \\
\hline 33 & Aliphatic C-C groups \\
56 & Methoxyl carbons \\
60 & Aliphatic C-O carbons other than methoxyl \\
72 & Polysaccharides \\
74 & Aliphatic C-O carbons other than methoxyl \\
84 & Aliphatic C-O carbons other than methoxyl \\
115 & C-2, C-5 and C-6 carbons of guaiacyl units \\
135 & C-substituted aromatic carbons C-1 or un-substituted aromatic carbons that \\
& are not ortho or para to O-substitution sites on aromatic rings \\
148 & C-3 and C-4 carbons of guaiacyl units \\
180 & Carbonyl and carboxylic acid structures \\
\hline
\end{tabular}


Table 4. Minimum complex viscosity and temperature of maximum fluidity for pristine pine Kraft lignin (PKL), lignin torrefied at different temperatures and using different heating rates (TL) and high rank good coking coal.

\begin{tabular}{|c|c|c|c|c|c|}
\hline & PKL & $\begin{array}{c}\mathrm{TL}\left(250^{\circ} \mathrm{C}, 1 \mathrm{~h},\right. \\
\left.3^{\circ} \mathrm{C} / \mathrm{min}\right)\end{array}$ & $\begin{array}{c}\mathrm{TL}\left(300^{\circ} \mathrm{C}, 1 \mathrm{~h},\right. \\
\left.3^{\circ} \mathrm{C} / \mathrm{min}\right)\end{array}$ & $\begin{array}{c}\mathrm{TL}\left(300^{\circ} \mathrm{C}, 1 \mathrm{~h},\right. \\
\left.20^{\circ} \mathrm{C} / \mathrm{min}\right)\end{array}$ & Coal \\
\hline$\eta^{*}{ }_{\min }\left({ }^{\circ}\right)$ & 907 & 14700 & 79900 & 37600 & 14300 \\
\hline $\mathrm{T}_{\mathrm{mf}}\left({ }^{\circ} \mathrm{C}\right)$ & 218 & 257 & 328 & 321 & 462 \\
\hline
\end{tabular}

Table 5. Mean hydrochar yields and their standard deviation values calculated from different hydrous pyrolysis tests and biocoke/coke yields obtained from the hydrochars and coal as determined by thermogravimetric analysis. Hydrochars were obtained at $350{ }^{\circ} \mathrm{C}$ for 6 hours using $30 \mathrm{ml}$ of water from pristine lignin (HL), torrefied lignin (HTL) and their 50:50 wt. $\% /$ wt. $\%$ blend (HB).

\begin{tabular}{lcccc}
\hline & HL & HTL & HB & Coal \\
\hline Hydrochar yield, mean (\%) & 60.7 & 84.3 & 77.4 & - \\
Std. deviation & 3.3 & 1.3 & 2.2 & - \\
Number of hydrous pyrolysis tests & 14 & 16 & 15 & - \\
\hline Biocoke/coke yield (\%) & 67 & 73 & 70 & 77 \\
\hline
\end{tabular}

Table 6. TG/DTG analysis results for the hydrochars obtained at $350{ }^{\circ} \mathrm{C}$ for 6 hours using 30 $\mathrm{ml}$ of water from pristine lignin (HL), torrefied lignin (HTL) and their 50:50 wt.\%/wt.\% blend (HB) and for the high rank good coking coal.

\begin{tabular}{lcccc}
\hline & HL & HTL & HB & Coal \\
\hline $\mathrm{T}_{\mathrm{i}}\left({ }^{\circ} \mathrm{C}\right)$ & 134 & 167 & 141 & 332 \\
$\mathrm{VM} 300(\%)$ & 30.1 & 10.8 & 21.3 & 1.1 \\
$\mathrm{VM} 400(\%)$ & 44.0 & 19.5 & 33.4 & 6.4 \\
$\mathrm{VM} 500(\%)$ & 61.0 & 37.3 & 51.8 & 45.5 \\
VM400-500 (\%) & 17.0 & 17.8 & 18.4 & 39.0 \\
$\mathrm{VM750}(\%)$ & 91.9 & 81.3 & 89.9 & 89.6 \\
$\mathrm{VM}^{\circ}(\% 0-500(\%)$ & 30.8 & 44.0 & 38.1 & 44.1 \\
$\mathrm{DTG}_{\max 1}$ & 0.585 & 0.209 & 0.413 & - \\
$\mathrm{T}_{\max 1}\left({ }^{\circ} \mathrm{C}\right)$ & 157 & 239 & 250 & - \\
$\mathrm{DTG}_{\max 2}$ & 0.612 & 0.718 & 0.71 & - \\
$\mathrm{T}_{\max 2}\left({ }^{\circ} \mathrm{C}\right)$ & 239 & 544 & 499 & - \\
$\mathrm{DTG}_{\max 3}$ & 0.670 & 0.288 & 0.205 & 1.560 \\
$\mathrm{~T}_{\max 3}\left({ }^{\circ} \mathrm{C}\right)$ & 501 & 789 & 812 & 486 \\
$\mathrm{~T}_{\mathrm{f}}\left({ }^{\circ} \mathrm{C}\right)$ & 900 & 969 & 892 & 928 \\
\hline
\end{tabular}


Table 7. Micro-strength indices and reactivity values measured with the ECE-INCAR method for the biocokes obtained from the lignin hydrochar (HL) and the 50:50 wt.\%/wt.\% blend hydrochar (HB) and for the coke obtained from the high rank good coking coal.

\begin{tabular}{lccc}
\hline & Biocoke (HL) & Biocoke (HB) & Coke \\
\hline $\mathrm{R}_{1}(\%)$ & 0.4 & 0.8 & 16.9 \\
$\mathrm{R}_{2}(\%)$ & 30.6 & 25.2 & 44.1 \\
$\mathrm{R}_{3}(\%)$ & 69.0 & 74.0 & 39.0 \\
Reactivity (\%) & 45.1 & 57.0 & 9.8 \\
\hline
\end{tabular}

Table 8. Surface areas determined through $\mathrm{CO}_{2}$ adsorption and textural parameters for the biocokes obtained from the lignin hydrochar (HL) and the 50:50 wt.\%/wt.\% blend hydrochar (HB) and for the coke obtained from the high rank coal.

\begin{tabular}{lccc}
\hline & Biocoke $(\mathrm{HL})$ & Biocoke $(\mathrm{HB})$ & Coke \\
\hline $\mathrm{W}_{0}\left(\mathrm{~cm}^{3} / \mathrm{g}\right)$ & 0.135 & 0.204 & 0.046 \\
$\mathrm{E}_{0}(\mathrm{~kJ} / \mathrm{mol})$ & 27.91 & 29.10 & 28.35 \\
$\mathrm{~L}(\mathrm{~nm})$ & 0.654 & 0.610 & 0.637 \\
$\mathrm{~S}_{\mathrm{mi}}\left(\mathrm{m}^{2} / \mathrm{g}\right)$ & 414 & 615 & 145 \\
$\mathrm{~V}_{\mathrm{T}}\left(\mathrm{cm}^{3} / \mathrm{g}\right)$ & 0.364 & 0.371 & 0.251 \\
$\mathrm{Macropore} \mathrm{volume} \%)$ & 30.3 & 34.5 & 41.4 \\
Mesopore volume $(\%)$ & 7.2 & 4.3 & 2.8 \\
Micropore volume $(\%)$ & 62.6 & 61.2 & 55.8 \\
$\rho_{\text {He }}\left(\mathrm{cm}^{3} / \mathrm{g}\right)$ & 1.781 & 1.919 & 1.473 \\
$\rho_{\mathrm{Hg}}\left(\mathrm{cm}^{3} / \mathrm{g}\right)$ & 1.081 & 1.120 & 1.075 \\
Porosity $(\%)$ & 39 & 42 & 27 \\
\hline
\end{tabular}




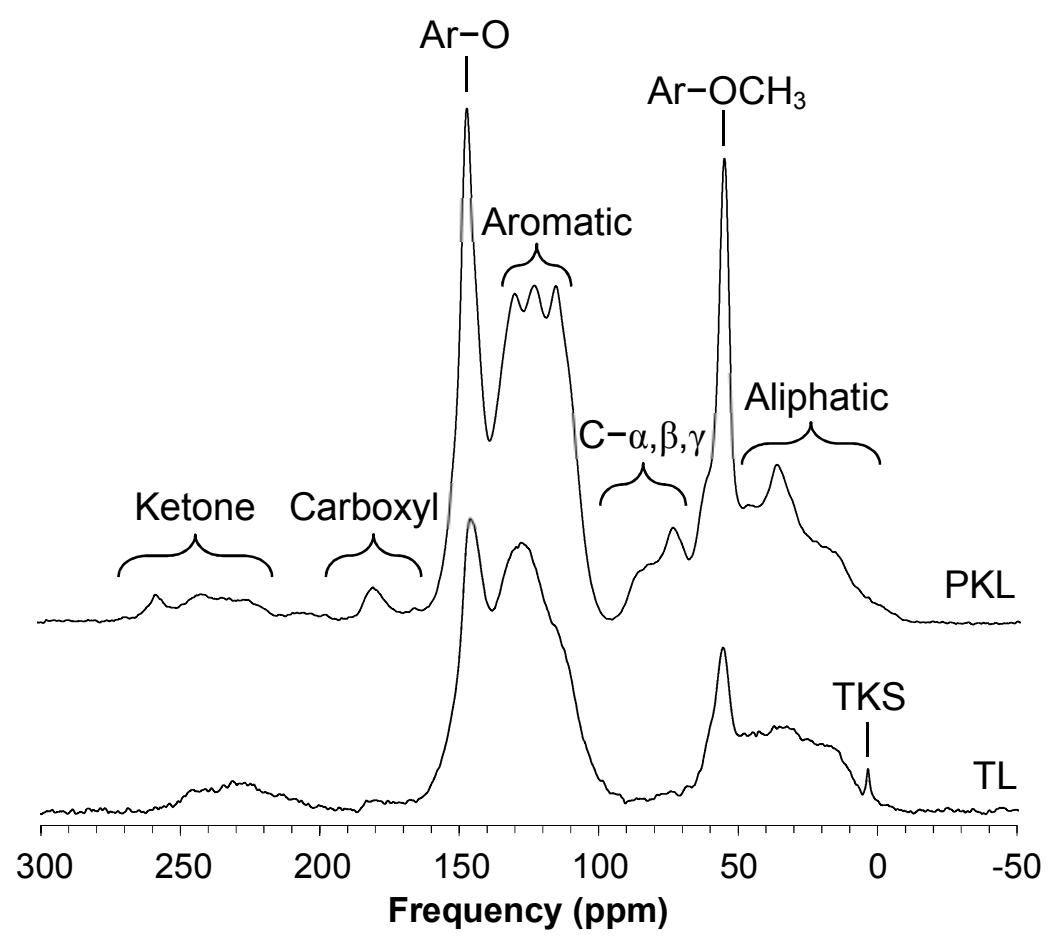

Fig. 1. Solid-state CP/MAS ${ }^{13} \mathrm{C}$ NMR spectra of pine Kraft lignin (PKL) and the lignin after torrefaction at $300{ }^{\circ} \mathrm{C}$ for 1 hour using a heating rate of $3{ }^{\circ} \mathrm{C} / \mathrm{min}$ (TL). Peak assignments adapted from Sharma et al. [23].

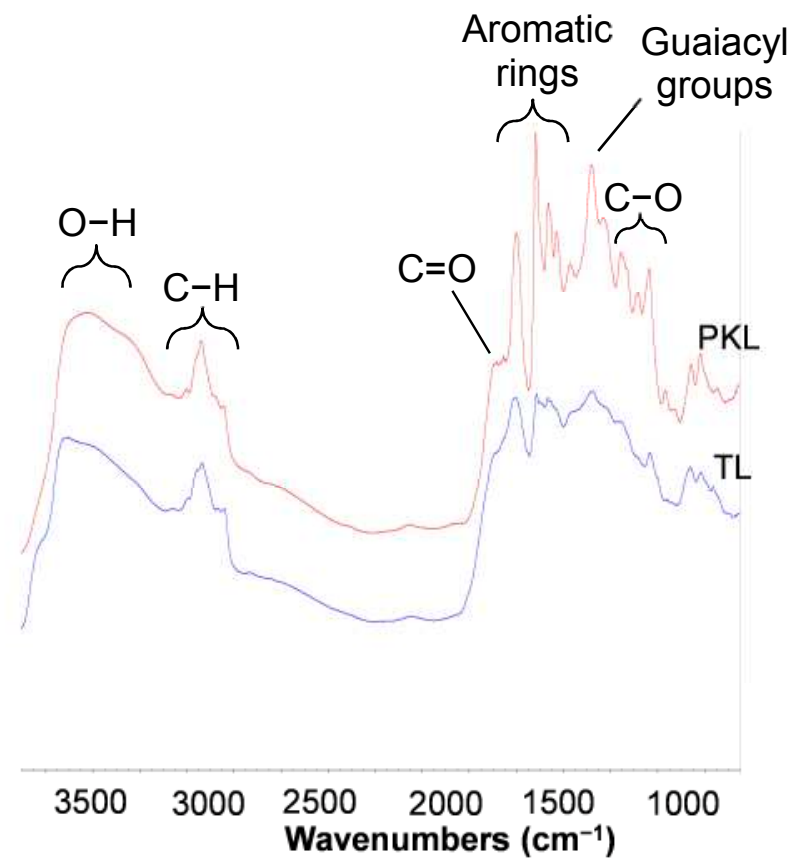

Fig. 2. DRIFTS spectra of the pristine lignin (PKL) and lignin torrefied at $300{ }^{\circ} \mathrm{C}$ for 1 hour using a heating rate of $3{ }^{\circ} \mathrm{C} / \mathrm{min}$ (TL). Peak assignments adapted from references [26,27]. 


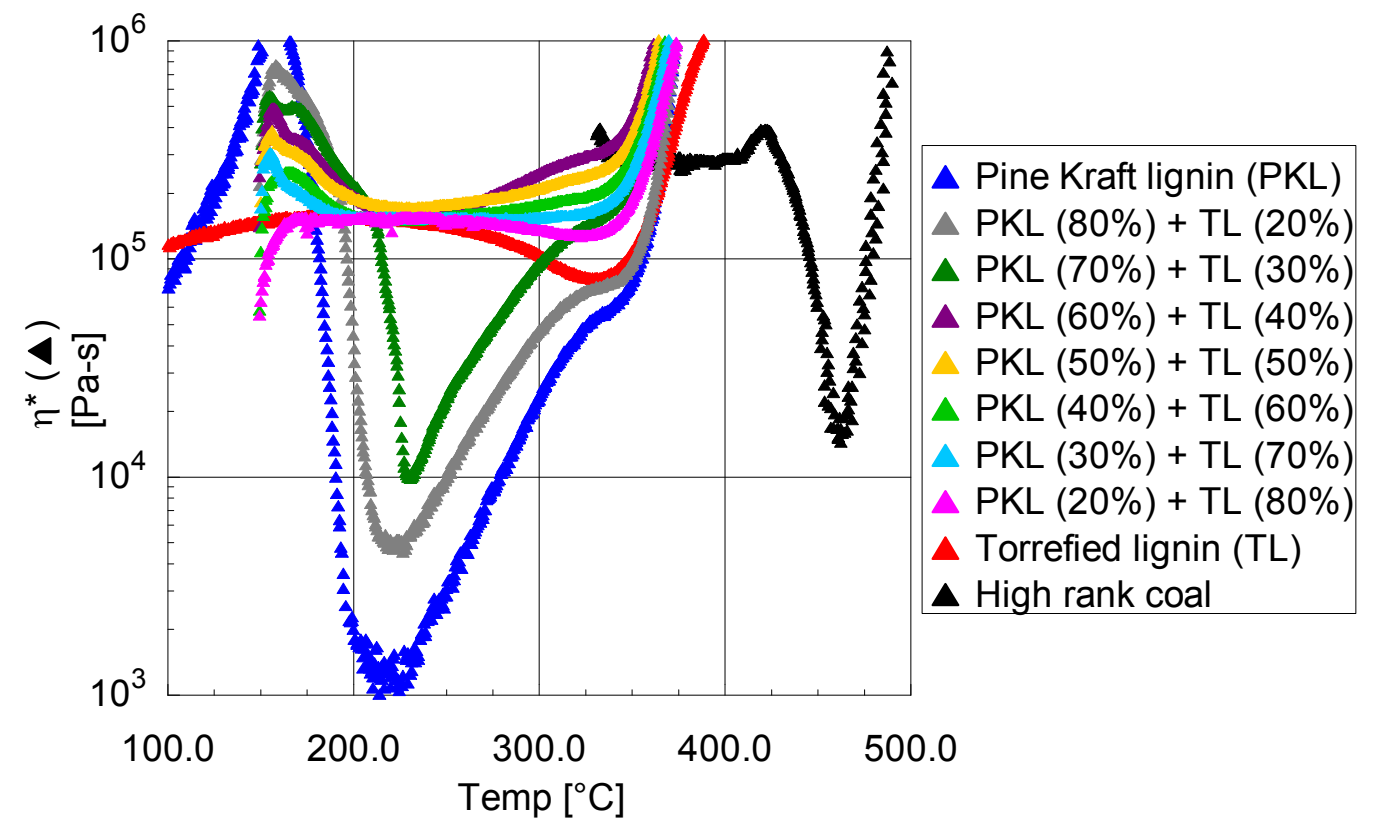

Fig. 3. Complex viscosity as a function of temperature for pristine pine Kraft lignin, lignin torrefied at $300{ }^{\circ} \mathrm{C}$ for 1 hour using a heating rate of $3{ }^{\circ} \mathrm{C} / \mathrm{min}$, their blends and the high rank good coking coal.

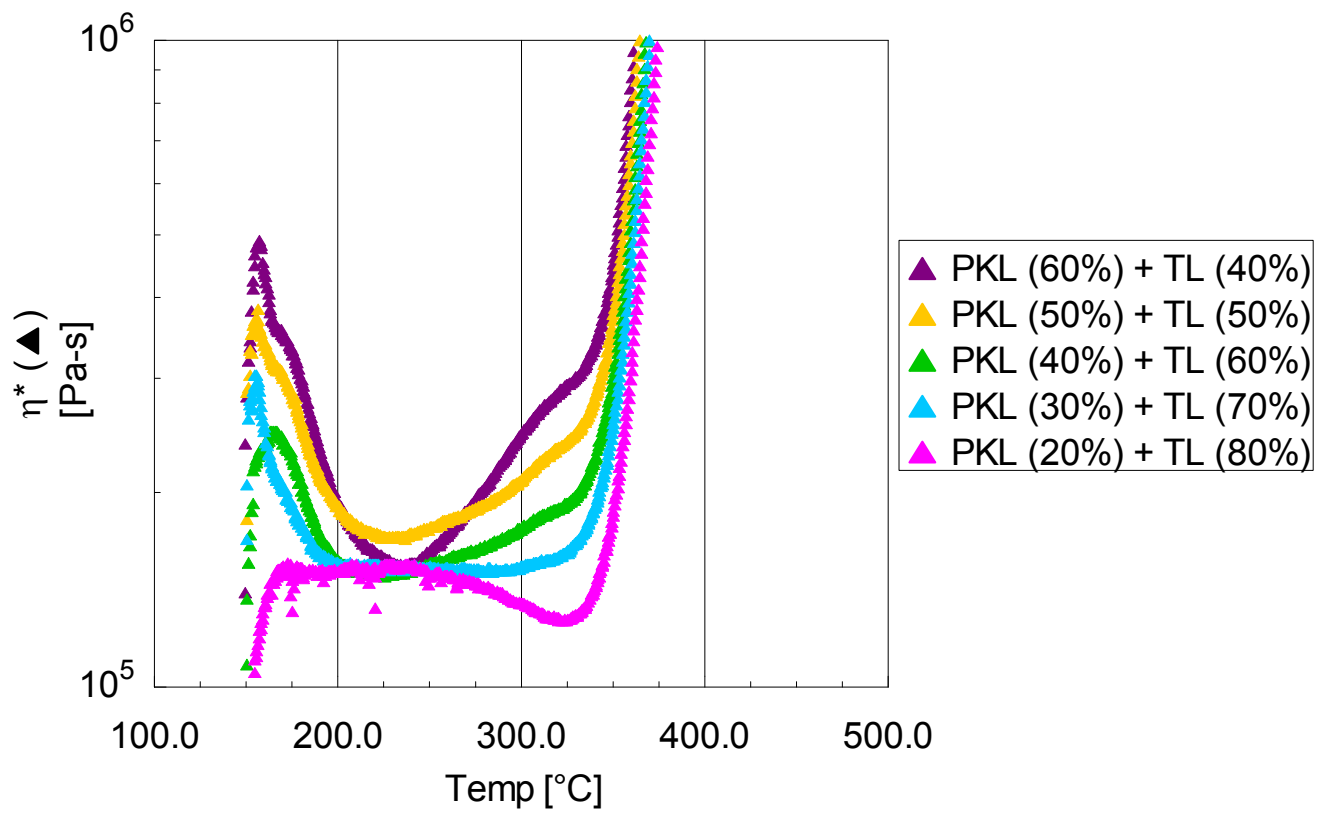

Fig. 4. Complex viscosity as a function of temperature for the blends of pine Kraft lignin (PKL) and lignin torrefied at $300{ }^{\circ} \mathrm{C}$ for 1 hour using a heating rate of $3{ }^{\circ} \mathrm{C} / \mathrm{min}$ (TL) containing between $20-60 \mathrm{wt} . \%$ of PKL. 


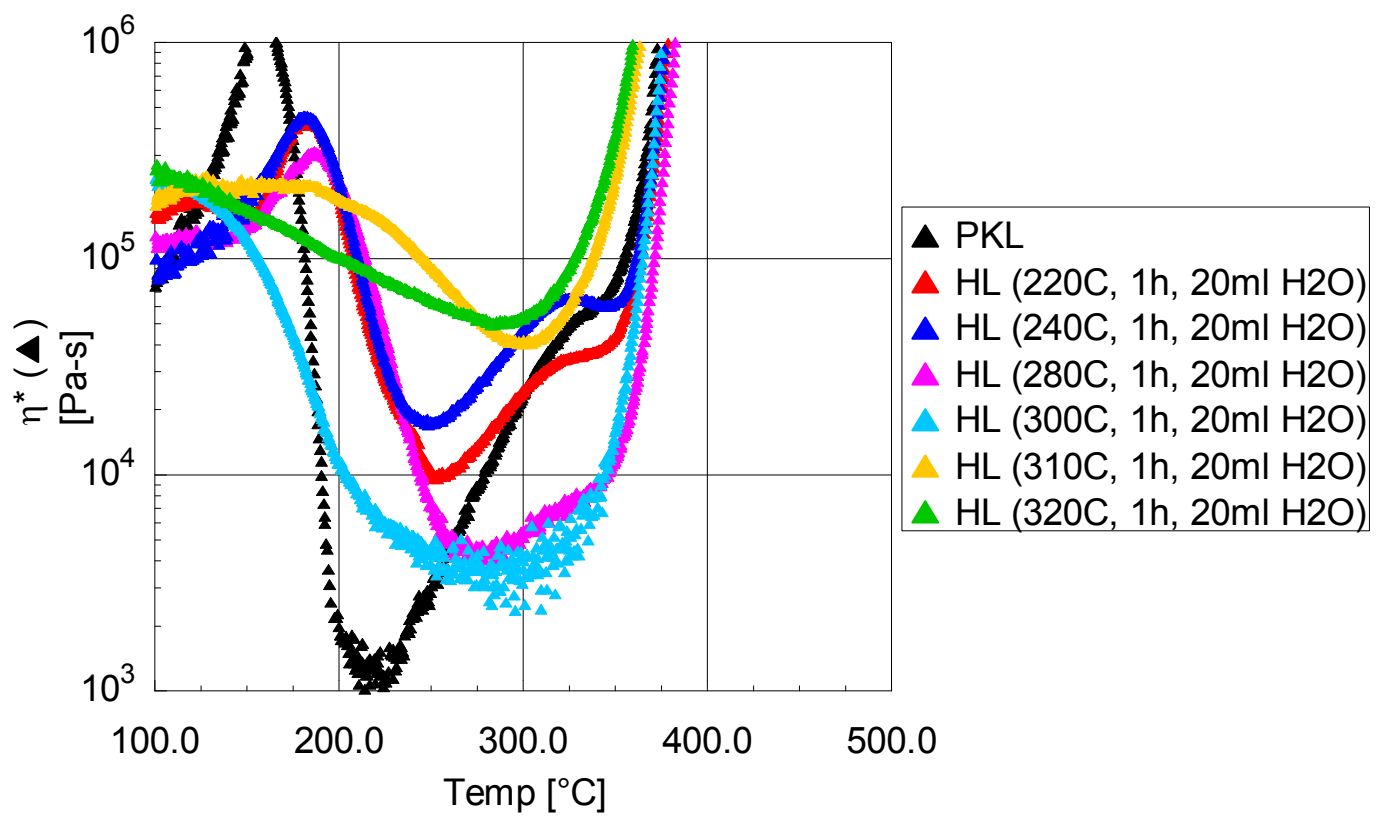

Fig. 5. Complex viscosity as a function of temperature for pine Kraft lignin (PKL) and the hydrochars obtained from lignin at different temperatures for 1 hour using $20 \mathrm{ml}$ of water (HL). 

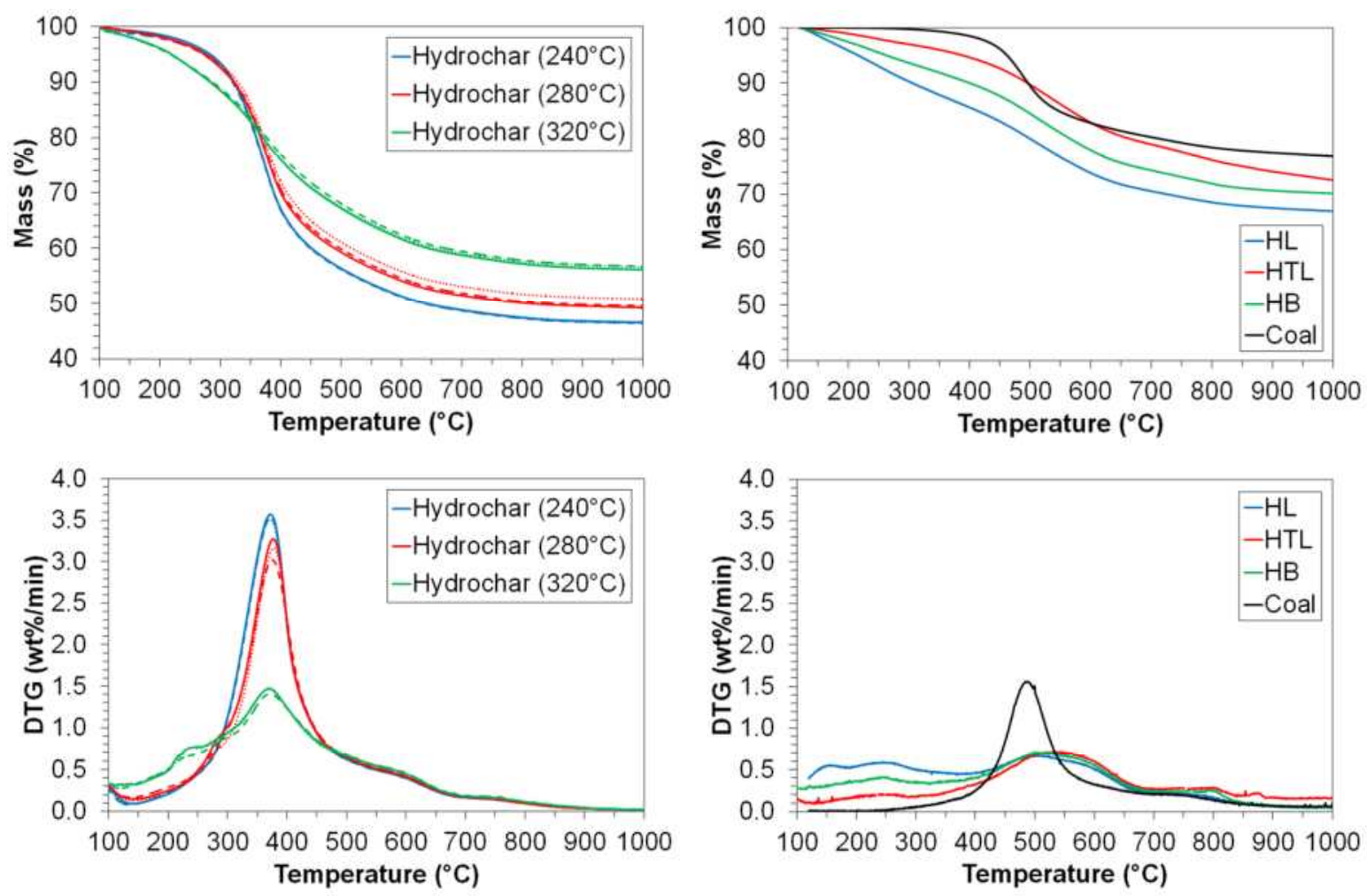

Fig. 6. TGA/DTG profiles as a function of temperature for the hydrochars obtained after hydrous pyrolysis of pine Kraft lignin at $240{ }^{\circ} \mathrm{C}, 280{ }^{\circ} \mathrm{C}$ and $320^{\circ} \mathrm{C}$ for 1 hour using $20 \mathrm{ml}$ of water (left) and for the high rank coking coal and the hydrochars obtained after hydrous pyrolysis at $350{ }^{\circ} \mathrm{C}$ for 6 hours using $30 \mathrm{ml}$ of water of pristine lignin (HL), lignin torrefied at $300{ }^{\circ} \mathrm{C}$ for 1 hour using a heating rate of $3{ }^{\circ} \mathrm{C} / \mathrm{min}$ (HTL) and their $50: 50 \mathrm{wt} . \% / \mathrm{wt} . \%$ blend (HB) (right). 

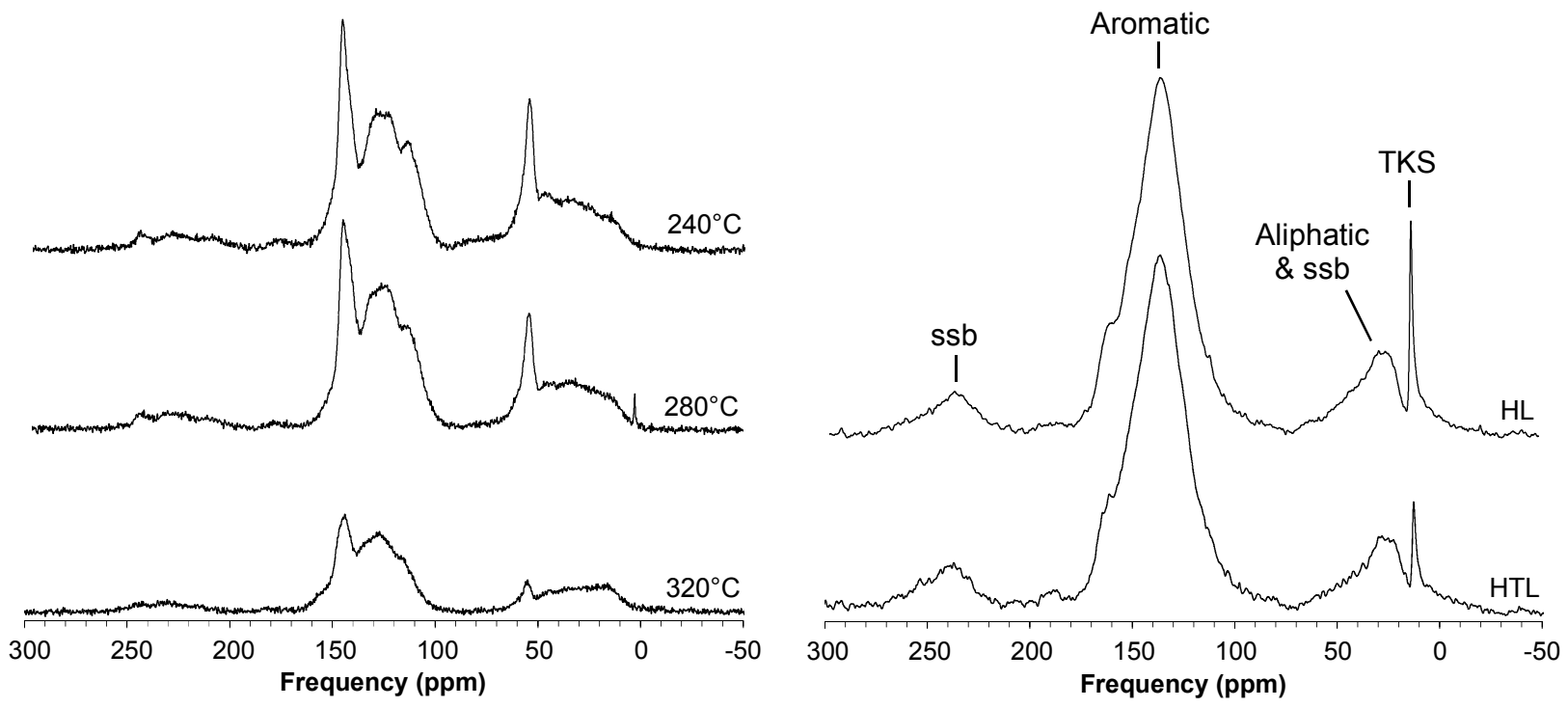

Fig. 7. Solid-state $\mathrm{CP} / \mathrm{MAS}{ }^{13} \mathrm{C}$ NMR spectra of the hydrochars obtained at $240{ }^{\circ} \mathrm{C}, 280{ }^{\circ} \mathrm{C}$ and $320^{\circ} \mathrm{C}$ for 1 hour using $20 \mathrm{ml}$ of water (left) and the hydrochars obtained after hydrous pyrolysis at $350^{\circ} \mathrm{C}$ for 6 hours using $30 \mathrm{ml}$ of water of pristine lignin (HL) and lignin torrefied at $300{ }^{\circ} \mathrm{C}$ for 1 hour using a heating rate of $3{ }^{\circ} \mathrm{C} / \mathrm{min}$ (HTL) (right). Spinning sidebands (ssb) originate from the aromatic carbon positioned at $130 \mathrm{ppm}$. 


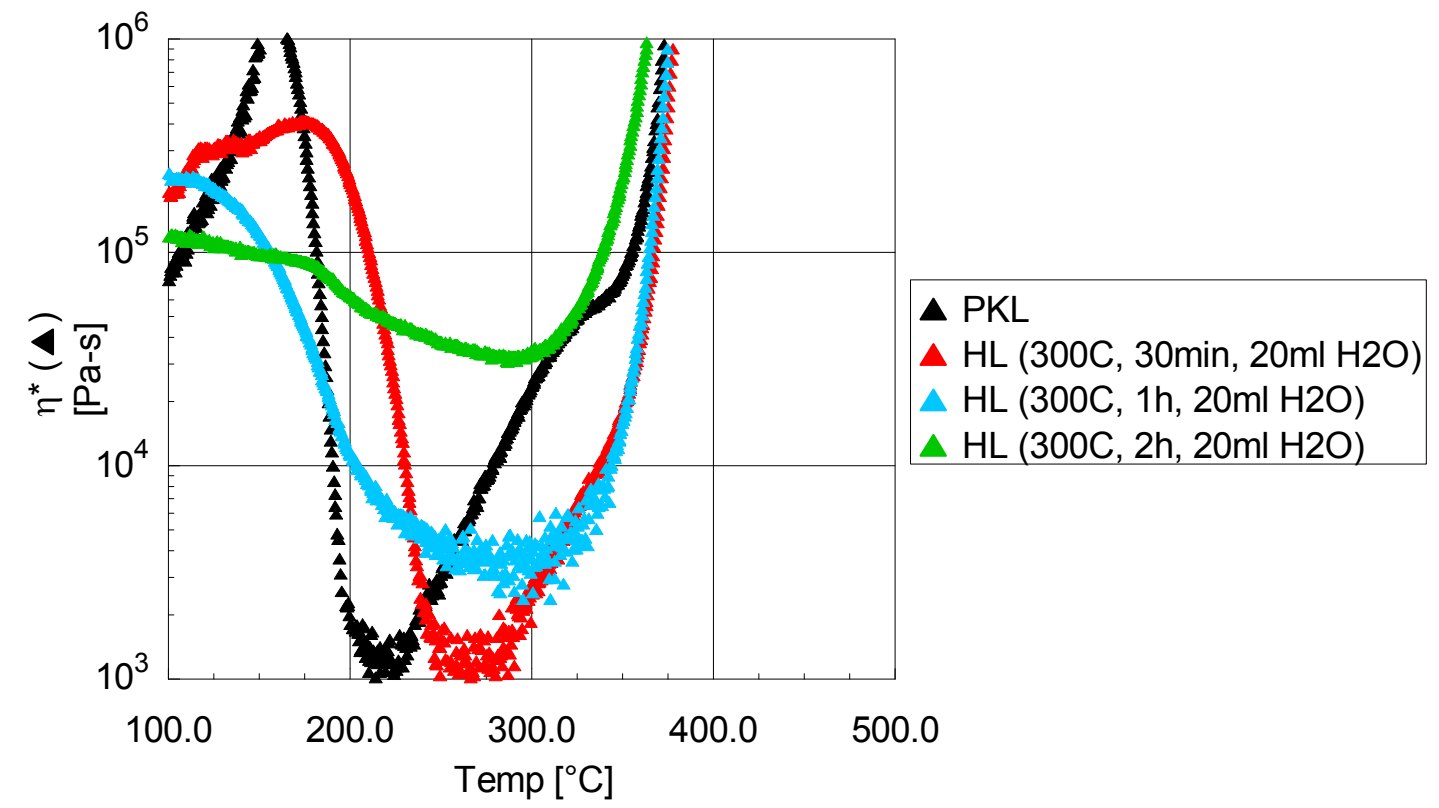

Fig. 8. Complex viscosity as a function of temperature for pine Kraft lignin (PKL) and the hydrochars obtained from lignin at $300{ }^{\circ} \mathrm{C}$ using $20 \mathrm{ml}$ of water and different residence times (HL).

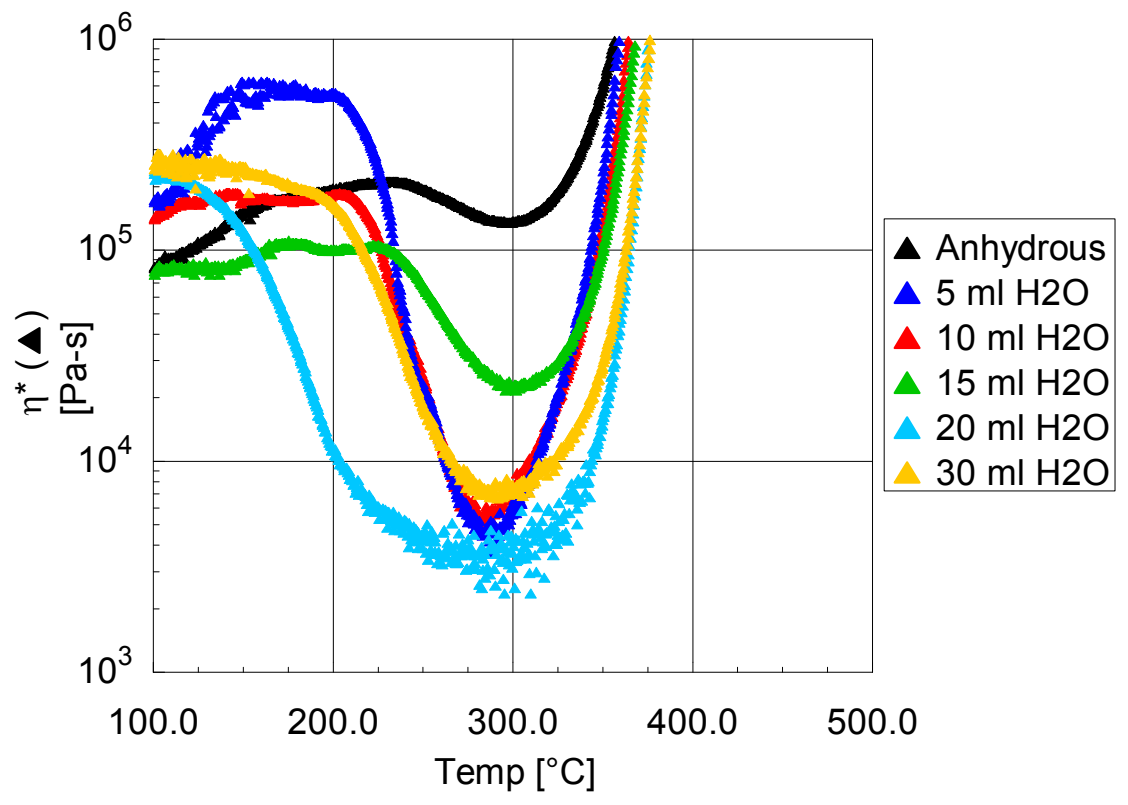

Fig. 9. Complex viscosity as a function of temperature for the hydrochars obtained from pine Kraft lignin at $300{ }^{\circ} \mathrm{C}$ for 1 hour using different amounts of water. 


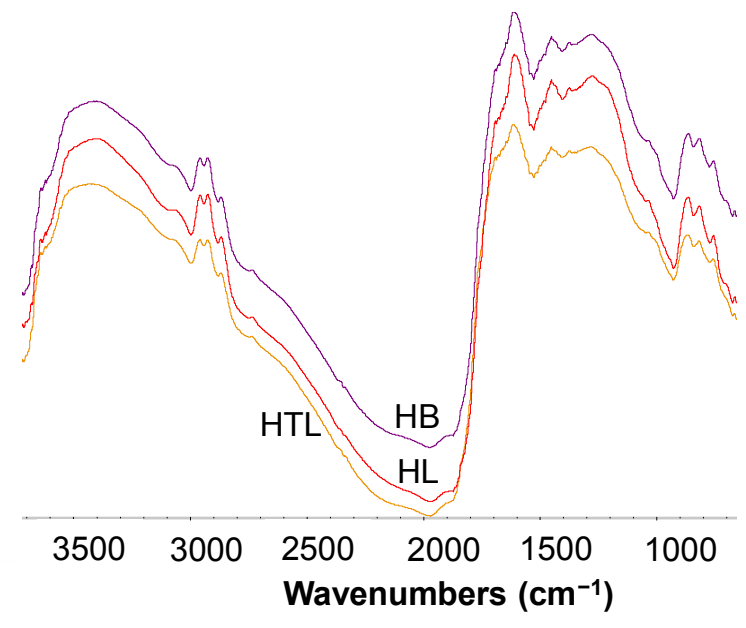

Fig. 10. DRIFTS spectra of the hydrochars obtained after hydrous pyrolysis at $350{ }^{\circ} \mathrm{C}$ for 6 hours using $30 \mathrm{ml}$ of water of pristine lignin (HL), lignin torrefied at $300{ }^{\circ} \mathrm{C}$ for 1 hour using a heating rate of $3{ }^{\circ} \mathrm{C} / \mathrm{min}$ (HTL) and their 50:50 wt.\%/wt.\% blend (HB).

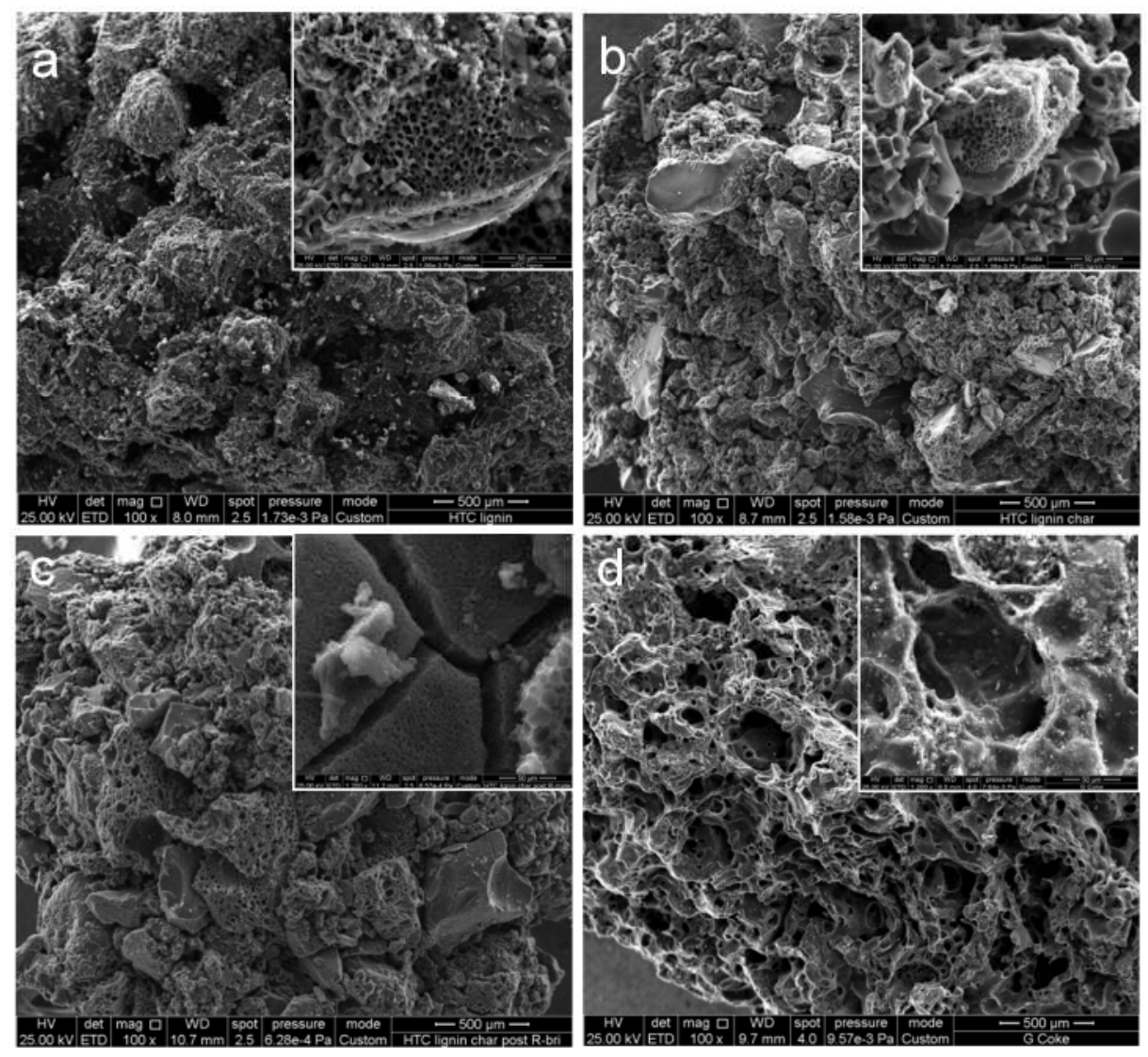

Fig. 11. FE-SEM images at magnification of $\times 100$ of hydrous pyrolysed lignin at $350{ }^{\circ} \mathrm{C}$ for 6 hours using $30 \mathrm{ml}$ of water (a), biocoke from hydrous pyrolysed lignin (b), biocoke from hydrous pyrolysed lignin and after $\mathrm{CO}_{2}$ reactivity test (c) and coke from high rank good coking coal (d). Inner images taken with a magnification of $\times 1200$. 